Article

\title{
Exergy Analysis and Performance Improvement of a Subcritical/Supercritical Organic Rankine Cycle (ORC) for Exhaust Gas Waste Heat Recovery in a Biogas Fuelled Combined Heat and Power (CHP) Engine Through the Use of Regeneration
}

\author{
Yıldız Koç@, Hüseyin Yağlı@ and Ali Koç*(i) \\ Department of Mechanical Engineering, Iskenderun Technical University, Hatay 31200, Turkey; \\ yildiz.koc@iste.edu.tr (Y.K.); huseyin.yagli@iste.edu.tr (H.Y.) \\ * Correspondence: ali.koc@iste.edu.tr; Tel.: +90-(533)-618-3358 (TR)
}

Received: 14 January 2019; Accepted: 7 February 2019; Published: 13 February 2019

\begin{abstract}
In the present study, a subcritical and supercritical regenerative organic Rankine cycle (rORC) was designed. The designed rORCs assist a combined heat and power (CHP) engine, the fuel of which is biogas produced from anaerobic digestion of domestic wastes in Belgium. R245fa was selected as the working fluid for both the subcritical and supercritical rORC. During the parametric optimisation, the net power production, mass flow rate, exchanged heat in the regenerator, total pump power consumption, thermal and exergetic efficiencies of rORC were calculated for varying turbine inlet temperatures and pressures. After parametric optimisation of the rORC, the results were compared with the results of the previous study, in which only a simple ORC is analysed and parametrically optimised. Moreover, the effect of the regenerator was revealed by examining all results together. Finally, the exergetic analysis of the best performing subcritical and supercritical rORC was performed. Furthermore, the results of the present and previous studies were considered together and it is clearly seen that the subcritical rORC shows the best performance. Consequently, by using the subcritical rORC, the disadvantages of the using simple ORC (low performance) and supercritical cycle (safety, investment) can be eliminated and system performance can be improved.
\end{abstract}

Keywords: combined heat and power (CHP); regenerative organic Rankine cycle (rORC); the effect of the regenerator; exhaust gas; subcritical; supercritical; parametric optimization; exergy

\section{Introduction}

In recent decades, energy has become one of the key factors to be a powerful country for both developing and developed countries [1]. Some countries have their own natural energy sources, fossil fuels, which will be depleted in the near future. However, many countries have no fossil fuel sources or they have only a limited amount. Therefore, all countries, whether they have fossil fuel sources or not, strive to produce their energy from alternative energy sources [2-4]. Consequently, nuclear energy and renewable energy sources such as solar [5], wind [6,7], geothermal [8] and biomass [9], which are sustainable and environmentally friendly, draw the attention of most governments, technology companies and scientists. Biogas, one of the anaerobic digestion products, is also among the most attractive alternative energy sources [10-13]. There are various biogas utilisation systems like stoves, fuel cells, gas turbines and hydrogen production systems [14-19]. Combined heat and power (CHP) engines also widely use biogas as an energy source [20-22]. However, the average efficiency of a CHP engine ranges from $30 \%$ to $45 \%$ [23-25]. The remaining energy coming from the 
biogas is released into the environment as waste visa the exhaust gas (about $26-45 \%$ ) and engine cooling water (almost reaches up to 40\%) [26-28]. Therefore, alternative waste heat recovery technologies which are adapted to these systems were developed to improve overall CHP engine efficiency. One of the ways to recover the waste heat of a CHP engine is organic Rankine cycles. The organic Rankine cycles have the capability of recovering waste heat even it is low temperature heat sources $\left(80^{\circ} \mathrm{C}\right.$ and above) $[29,30]$.

Both conventional steam Rankine cycles and organic Rankine cycles (ORC) have similar system components. However, the ORC has superiority when used for low temperature heat sources. In literature, there are many studies which use ORC to assist low (between 80-200 ${ }^{\circ} \mathrm{C}$ ) temperature heat sources. Preißinger et al. thermodynamically analysed a modular organic Rankine cycle for a low temperature heat source [31]. Chen et al. analysed the use of a low heat carrying source to produce power by using a supercritical ORC which uses azeotropic mixtures as a working fluid. It was seen from the results that the designed ORC could achieve a thermal efficiency range from $10.8 \%$ to $13.4 \%$ [32]. Manfrida et al. designed and simulated a solar system-assisted ORC for a temperature range between $363 \mathrm{~K}$ and $403 \mathrm{~K}$. As a result of a simulation for a week, a weekly average thermal efficiency of the designed cycle was calculated as nearly $13.4 \%$ [33]. Hettiarachchi et al. determined the optimum design parameters of an ORC assisted by a low-temperature geothermal heat source. During the study ammonia, HCFC123, n-pentane and PF5050 were considered as a working fluid and they found that performance of the ORC with HCFC 123 and n-pentane was better than the other working fluid [34].

On the other hand, there are also many studies which tend to connect the ORC to high $\left(450{ }^{\circ} \mathrm{C}\right.$ and above) and moderate (between $200-450{ }^{\circ} \mathrm{C}$ ) temperature heat sources. Yagli et al. compared toluene and cyclohexane as working fluids for an ORC designed for the high temperature exhaust gas of a reheat furnace. Results showed that the ORC using cyclohexane gave better results than the ORC that used toluene for the same working conditions [35]. Lai et al. analysed the performance of subcritical and supercritical ORCs for different working fluids. They found that cyclopentane has the maximum potential to recover waste heat for all cases studied in the paper [36]. A comparative energetic analysis of a high temperature subcritical and transcritical ORC was performed by Algieri and Morrone. After a detailed analysis, a significant improvement in the overall cycle efficiency with the use of supercritical conditions and an internal heat exchange system was reported [37]. Fiaschi et al. performed an exergoeconomic-based analysis of an ORC to recover low and medium-high temperature heat from two different geothermal sources [30].

There are also heat sources which have a high temperature but low mass flow rate and limited waste heat capacity to recover, such as car engine exhaust gases, the cooling water of many systems, etc. [38-40]. The exhaust gas waste heat of small and medium scale combined heat and power (CHP) engines are also constitutes of these limited systems. The exhaust gas of a CHP engine has a small amount of the mass flow rate but high temperature. A few studies were conducted to show the capacity of the organic Rankine cycle connected to CHP engines. Benato and Macor analysed the recoverability potential of exhaust gas waste heat of a biogas fuelled engine using ORC [41]. Glover et al. simulated a supercritical ORC with many working fluids to recover the waste heat from a vehicle engine. As a result of the study, the cycle performances of fluids with high critical temperatures were reported to be better. Moreover, when all simulations studied in the paper were regarded, a thermal efficiency between $5 \%$ and $23 \%$ was found [ 42 ].

Like main energy systems, ORCs also need optimisation and improvement up to their maximum usable capacity. In addition to optimizing the system parameters or working fluids of the ORC cycles, there are a number of studies aimed at improving the efficiency of the ORC components. Redesign and optimization of turbines and pumps are examples of these improvement efforts [43-45]. The use of a regenerator and operating in supercritical conditions is also often applied to improve the system performance [46-51]. When the previous studies are examined in detail, it becomes obvious that there are many studies that reveal the capacity of ORCs to recover waste heat from different sources, but only some of them analyse the probability of using organic Rankine cycles to assist small and medium 
scale CHP engines. Moreover, only a few studies examine the parametric optimisation of the ORC and almost all of them examine the ORC with regard to only one of the subcritical and supercritical operating conditions. There is almost no work that examines the effects of the regenerator on the ORC in detail and examines it in detail under subcritical and supercritical conditions. The present study examines the important role of the effect of regenerators on ORCs for both subcritical and supercritical conditions. The effects of the turbine inlet pressure and temperature on regenerative ORC performance are also evaluated. Additionally, the critical point of the study is that the exhaust gas waste heat of a $\mathrm{CHP}$ engine is used to reveal the effect of regenerator as well as the effect of subcritical and supercritical working conditions, which is one of the topics with limited studies in the literature.

In this paper, recoverability of the exhaust gas waste heat of a biogas fuelled combined heat and power $(\mathrm{CHP})$ engine was analysed by using a regenerative organic Rankine cycle (rORC). The designed rORC was parametrically optimised and the result of the present study was compared with the results of the previous study, in which only simple ORC is analysed and optimised [52]. This study has also shed light on the usability and working condition of a regenerator in both subcritical and supercritical ORCs by comparing the results evaluated from the present paper with the previous paper. After a detailed improvement of the rORC for varying turbine inlet temperature and pressure, the energetic and exergetic analysis of the best performing subcritical and supercritical rORC is executed. Throughout the study, the system is simulated by using EBSILON ${ }^{\circledR}$ Professional (EBSILON) software developed by Steag GmbH (Essen, Germany).

\section{Description of the System}

\subsection{Description of the Biogas Fuelled Power Plant}

The schematic representation of the biogas fuelled power plant is given in Figure 1. The plant is located in Belgium and has two biogas fuelled internal combustion engines which have a total electricity production capacity of $1068 \mathrm{~kW}$. The surplus jacket water heat is used for domestic heating at the houses located around the biogas fuelled power plant. The plant has two sequential processes which are biogas production and purification process and power production and local house heating process.

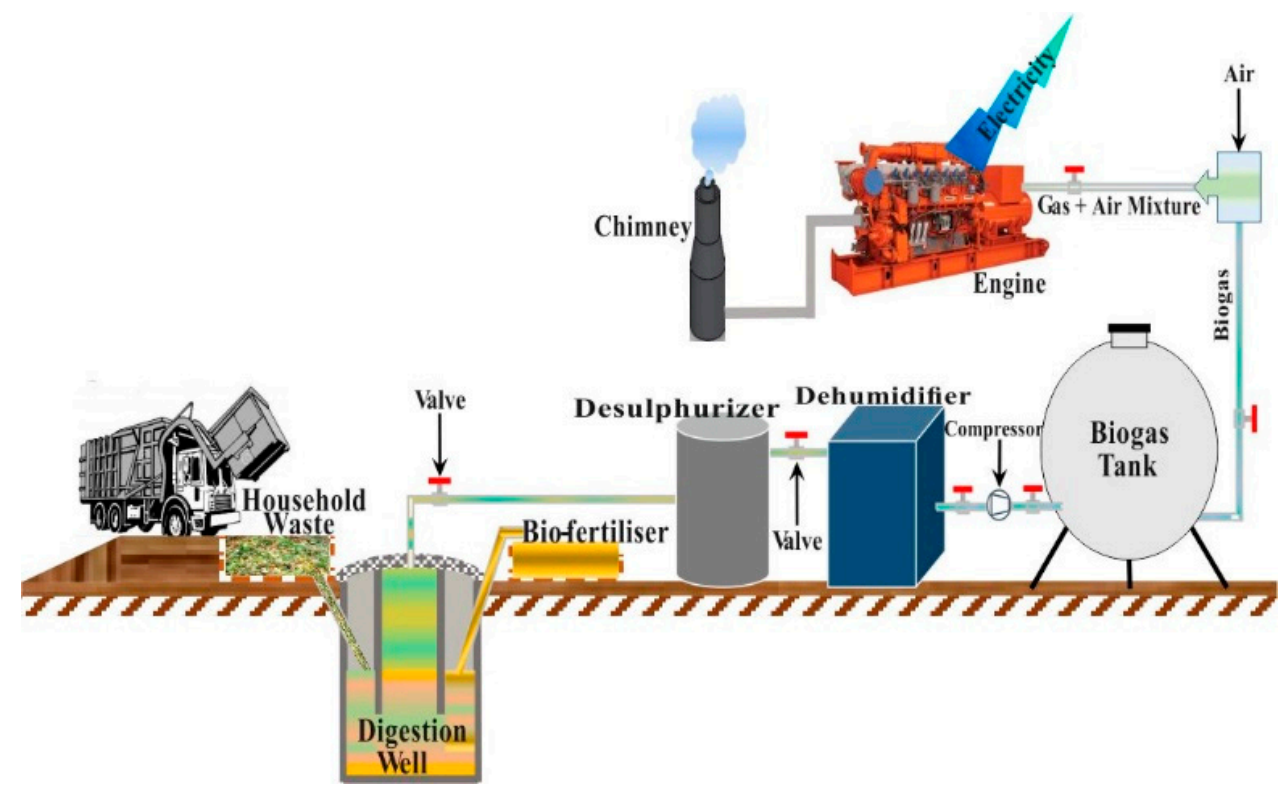

Figure 1. The schematic representation of the biogas fuelled power plant.

In the first process of the plant, the non-organic wastes like glass, plastics are removed from the collected domestic wastes and then the organic purified wastes are charged into the well for the digestion process. During the anaerobic fermentation, the temperature and $\mathrm{pH}$ of the well are 
kept under control by a control system. After the digestion process, two main products are obtained. The first one is the bio-fertiliser which has rich ingredients for farming. The second one is impure biogas. The impure biogas is sent to the desulphurizer and dehumidifier section to remove sulphur and moisture. The ultimately obtained biogas, which composed of $55 \% \mathrm{CH}_{4}$ and $45 \% \mathrm{CO}_{2}$, is stored in the biogas tank for power production by a combined heat and power engine.

\subsection{Description of the Combined Heat and Power (CHP) Engine}

The combined heat and power engine evaluated in this study has twelve cylinders and the engine is fuelled with biogas. Each engine in the plant has an electricity capacity of nearly $534 \mathrm{~kW}$. Currently, the heated jacket cooling water is coupled with a domestic house heating system. The energy of the high temperature exhaust gas released to the atmosphere is considered to use in organic Rankine cycle in the present paper. The plant has two CHP engines and a schematic description of the plant, CHP engine and ORC is given in Figure 2.

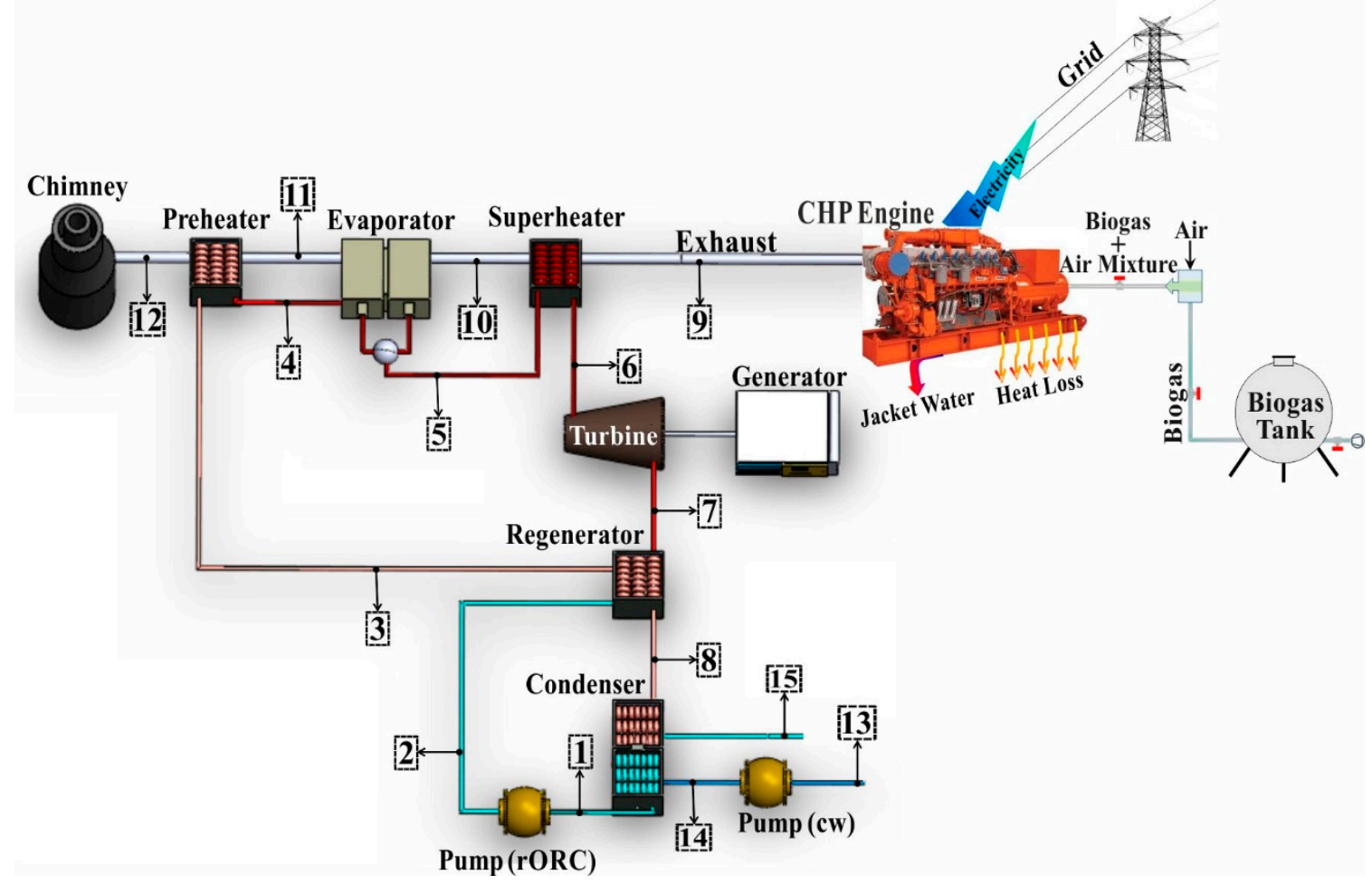

Figure 2. The schematic representation of the rORC-assisted CHP engine system.

In the CHP engine, biogas supplied from the plant is blended with air and then delivered to the heat exchanger by the compressor of the turbocharger. Before the injection of the compressed air-biogas mixture, in the heat exchanger, the mixture is cooled with an air cooler in warmer months and warmed by jacket water in colder months. While the air-biogas mixture is injected and burned in the engine, the lubrication oil is supplied from oil feeding unit in order to lubricate the engine.

After the exhaust gas of the engine is blown through the turbine of the turbocharger unit, the exhaust gas is released into the atmosphere at a temperature between $450{ }^{\circ} \mathrm{C}$ and $500{ }^{\circ} \mathrm{C}$. The jacket water used to keep the engine temperature under control is sent to a heat exchanger to heat up the house heating loop and then the water is transferred to the air coolers. In order to evaluate the best results, the operation conditions of the $\mathrm{CHP}$ engine is accepted to be nominal conditions, which are given in Table 1 in detail. 
Table 1. Nominal working conditions of each CHP engine for $100 \%$ load.

\begin{tabular}{ccc}
\hline & Value & Unit \\
\hline Engine number & 2 & - \\
Plant electricity production capacity & 1068 & $\mathrm{~kW}_{\mathrm{e}}$ \\
Engine electrical efficiency & $39.3 \%$ & - \\
Engine mechanical efficiency & $40.6 \%$ & - \\
Engine thermal efficiency & $37.2 \%$ & - \\
Exhaust gas mass flow rate (wet) & 2981 & $\mathrm{~kg} / \mathrm{h}$ \\
Exhaust gas temperature range & $450-500$ & ${ }^{\circ} \mathrm{C}$ \\
Exhaust gas power content ${ }^{*}$ & 285 & $\mathrm{~kW}$ \\
\hline${ }^{*}$ When exhaust gas is cooled to $180{ }^{\circ} \mathrm{C}$. &
\end{tabular}

Depending on the season and atmospheric temperature, the exhaust gas temperature varies from $450{ }^{\circ} \mathrm{C}$ to $500{ }^{\circ} \mathrm{C}$. Therefore, during the design and parametric optimisation procedure of the ORC, the exhaust gas temperature is assumed as constant at $450{ }^{\circ} \mathrm{C}$. The mass flow rate of the exhaust gas is also accepted as constant, $1.63 \mathrm{~kg} / \mathrm{s}$.

\subsection{Description of the rORC}

When compared to the conventional Rankine cycles, the organic Rankine cycle (ORC) has different working fluids and heat source temperature ranges, but similar working principles. The working fluids of the organic Rankine cycles are organic-based hydrocarbon fluids and low temperature waste heat of up to $80^{\circ} \mathrm{C}$ can be used as a heat source for the ORC. Water vapour is the only working fluid of the conventional Rankine cycle which uses heat sources that have a temperature above $500{ }^{\circ} \mathrm{C}$. These superiorities of the ORC make it one of the best ways to recover waste heat, especially for low and medium temperature waste heat sources. The schematic representation of the ORC-assisted CHP engine system is given in Figure 2. During the power production of the CHP engine, the engine loses heat by convection and conduction. The jacket water and exhaust gas also release excess heat from the engine. In the present case, the heated jacket water of the engine is used for domestic house heating for the buildings located around the plant and the hot exhaust gas is sent directly into the environment without being used. In the concept of the present study, a regenerative ORC (rORC) is designed to recover excess heat released to the atmosphere by exhaust gas.

Simple ORC systems have four separate system sections which are the compression section (pumps), hot section (preheater, evaporator, superheater), expansion section (turbine) and cooling section (condenser). Both the simple ORC system and the rORC system have similar system components, but the main difference between them is the use of a regenerator. In order to recover the waste heat of the exhaust easily and obtain superheated vapour at the turbine inlet, the rORC system designed in this study also includes three heat exchangers in the hot section [52]. Moreover, the rORC is analysed for both subcritical and supercritical cases together.

The turbine inlet pressure of the subcritical rORC is below the critical pressure, while the turbine inlet pressure of the supercritical rORC is above the critical point. For both subcritical and supercritical rORC design, the thermal efficiencies of the pumps and turbines are taken as constant. The pressure drop in the preheater, superheater and regenerator are taken as 0.001 bar at hot side and 0.05 bar at the cold side while the pressure drop in the evaporator and pipes are neglected. During the study, the temperature differences between the hot side regenerator outlet (line number 8 ) and cold side regenerator inlet (line number 2 ) is taken as constant at $5{ }^{\circ} \mathrm{C}$. Moreover, the working fluid in the regenerator on the hot side and the cold side has a different phase. Because of the phase differences, the effectiveness of the regenerator varies from $85 \%$ to $92 \%$, according to change in the pressure of the pump outlet. The additional design and parametric optimisation assumptions for the rORC are given in Table 2. 
Table 2. The additional design and parametric optimisation assumptions for the rORC.

\begin{tabular}{ccc}
\hline Parameter & Value & Unit \\
\hline Isentropic efficiency of the pumps & $80 \%$ & - \\
Isentropic efficiency of the turbine & $88 \%$ & - \\
Electrical efficiency of the generator & $98.5 \%$ & - \\
Condensing pressure & 2 & $\mathrm{bar}$ \\
Hot side pressure drop in the regenerator & 0.001 & $\mathrm{bar}$ \\
Cold side pressure drop in the regenerator & 0.05 & $\mathrm{bar}$ \\
Hot side pressure drop in the condenser & 0 & $\mathrm{bar}$ \\
Cold side pressure drop in the condenser & 0.5 & $\mathrm{bar}$ \\
Exhaust gas inlet temperature & 450 & ${ }^{\circ} \mathrm{C}$ \\
Exhaust gas outlet temperature & 150 & ${ }^{\circ} \mathrm{C}$ \\
Cooling water temperature at condenser inlet & 25 & ${ }^{\circ} \mathrm{C}$ \\
\hline
\end{tabular}

\section{Analysis Formulation and Working Fluid}

\subsection{Energy and Exergy Analysis Equations}

An extensive analysis of the rORC based on the first and second law of the thermodynamics has critical importance to decide the best performing cycle parameters. This study not only embraces the energetic analyses of the rORC but also provides an exergetic analysis because only the energetic analysis of a system is not enough to have a vision for the performance of the system. The analysis is applied to both subcritical and supercritical rORCs. The main mass, energy and exergy balance and efficiency equations used to analyse the rORC was detailly given in the previous manuscript and in the literature [53-55].

$$
\begin{gathered}
\sum \dot{m}_{i}=\sum \dot{m}_{o} \\
\dot{Q}+\dot{W}=\sum(\dot{m} h)_{o}-\sum(\dot{m} h)_{i} \\
\dot{E}_{e x ; i}=\dot{E}_{e x ; o}+\dot{E}_{e x ; D}
\end{gathered}
$$

where $\dot{E}_{e x ; i}, \dot{E}_{e x ; 0}$ and $\dot{E}_{e x ; D}$ represent the exergy inlet, exergy outlet and exergy destruction, respectively. $\dot{E}_{e x}$ represents the exergy flow rate and can be calculated by:

$$
\dot{E}_{e x}=\dot{m} \psi
$$

where $\psi$ refers to specific exergy and is calculated by:

$$
\psi=\left(h-h_{0}\right)-T_{0}\left(s-s_{0}\right)
$$

While the exergy efficiency of the work is $100 \%$, the exergy efficiency of the heat varies depending on the ambient temperature and the heat transfer surface temperature, so the exergy flow of the heat $\left(\dot{E}_{\text {ex;heat }}\right)$ should be calculated by:

$$
\dot{E}_{\text {ex;heat }}=\left(1-\frac{T_{0}}{T_{H S}}\right) \dot{Q}
$$

where the $T_{H S}$ is the heat transfer surface temperature and taken as the mean value of the working fluid inlet and outlet temperature. The $T_{0}$ is the dead state or ambient temperature which is taken as $18^{\circ} \mathrm{C}$ during the study.

The exergy analysis of the rORC components is made by using exergy balance equations and then the exergetic efficiencies of each component are calculated. The energetic and exergetic analysis of each component is determined by using the equations given in Table 3 . 
The overall energy and exergy efficiencies of the rORC are found by:

$$
\begin{gathered}
\eta_{r O R C}=\frac{\dot{W}_{n e t}}{\dot{Q}_{i n}} \\
\varepsilon_{r O R C}=\frac{\dot{E}_{e x ; o}}{\dot{E}_{e x ; i}}=\frac{\dot{W}_{n e t}}{\dot{E}_{e x ; i}}
\end{gathered}
$$

where $\dot{W}_{\text {net }}$ represents the net power production and calculated by:

$$
\dot{W}_{n e t}=\dot{W}_{T}-\dot{W}_{P(r O R C)}-\dot{W}_{P(c w)}
$$

During the calculations, the kinetic and potential energies are neglected and the condition of the

\begin{tabular}{|c|c|c|}
\hline Component & Energy Analysing Equations & Exergy Analysing Equations \\
\hline & $\dot{Q}_{P H}=\dot{m}_{r O R C}\left(h_{4}-h_{3}\right)$ & $\begin{array}{c}\dot{E}_{P H, D}=\dot{m}_{e x h}\left(\psi_{11}-\psi_{12}\right)-\dot{m}_{r O R C}\left(\psi_{4}-\psi_{3}\right) \\
\varepsilon_{P H}=\frac{\dot{m}_{r O R C}\left(\psi_{4}-\psi_{3}\right)}{\dot{m}_{e x h}\left(\psi_{11}-\psi_{12}\right)}\end{array}$ \\
\hline ator & $\dot{Q}_{E}=\dot{m}_{r O R C}\left(h_{5}-h_{4}\right)$ & $\begin{array}{c}\dot{E}_{E, D}=\dot{m}_{e x h}\left(\psi_{10}-\psi_{11}\right)-\dot{m}_{r O R C}\left(\psi_{5}-\psi_{4}\right) \\
\varepsilon_{E}=\frac{\dot{m}_{r O R C}\left(\psi_{5}-\psi_{4}\right)}{\dot{m}_{e x h}\left(\psi_{10}-\psi_{11}\right)}\end{array}$ \\
\hline & $\dot{Q}_{S H}=\dot{m}_{r O R C}\left(h_{6}-h_{5}\right)$ & $\begin{array}{c}\dot{E}_{S H, D}=\dot{m}_{e x h}\left(\psi_{9}-\psi_{10}\right)-\dot{m}_{r O R C}\left(\psi_{6}-\psi_{5}\right) \\
\varepsilon_{S H}=\frac{\dot{m}_{r O R C}\left(\psi_{6}-\psi_{5}\right)}{\dot{m}_{e x h}\left(\psi_{9}-\psi_{10}\right)}\end{array}$ \\
\hline & $\begin{array}{c}\dot{W}_{T}=\dot{m}_{r O R C}\left(h_{6}-h_{7}\right) \\
\eta_{T}=\frac{\left(h_{6}-h_{7}\right)}{\left(h_{6}-h_{7 s}\right)}\end{array}$ & $\begin{array}{c}\dot{W}_{T, r e v}=\dot{m}_{r O R C}\left(\psi_{6}-\psi_{7}\right) \\
\dot{E}_{T, D}=\dot{W}_{T, r e v}-\dot{W}_{T} \\
\varepsilon_{T}=\frac{\dot{W}_{T}}{\dot{W}_{T, r e v}}\end{array}$ \\
\hline & $\dot{Q}_{R}=\dot{m}_{r O R C}\left(h_{3}-h_{2}\right)$ & $\begin{array}{c}\dot{E}_{R, D}=\dot{m}_{r O R C}\left(\psi_{7}-\psi_{8}\right)-\dot{m}_{r O R C}\left(\psi_{3}-\psi_{2}\right) \\
\varepsilon_{R}=\frac{\dot{m}_{r O R C}\left(\psi_{3}-\psi_{2}\right)}{\dot{m}_{r O R C}\left(\psi_{7}-\psi_{8}\right)}\end{array}$ \\
\hline & $\dot{Q}_{C}=\dot{m}_{r O R C}\left(h_{8}-h_{1}\right)$ & $\begin{array}{c}\dot{E}_{C, D}=\dot{m}_{r O R C}\left(\psi_{8}-\psi_{1}\right)-\dot{m}_{c w}\left(\psi_{15}-\psi_{14}\right) \\
\varepsilon_{C}=\frac{\dot{m}_{c w}\left(\psi_{15}-\psi_{14}\right)}{\dot{m}_{r O R C}\left(\psi_{8}-\psi_{1}\right)}\end{array}$ \\
\hline Pump (rORC) & $\begin{array}{c}\dot{W}_{P(r O R C)}=\dot{m}_{r O R C}\left(h_{2}-h_{1}\right) \\
\eta_{P(r O R C)}=\frac{\left(h_{2 s}-h_{1}\right)}{\left(h_{2}-h_{1}\right)}\end{array}$ & $\begin{array}{c}\dot{W}_{P(r O R C), r e v}=\dot{m}_{r O R C}\left(\psi_{2}-\psi_{1}\right) \\
\dot{E}_{P(r O R C), D}=\dot{W}_{P(r O R C)}-\dot{W}_{P(r O R C), r e v} \\
\varepsilon_{P(r O R C)}=\frac{\dot{W}_{P(r O R C), r e v}}{\dot{W}_{P(r O R C)}}\end{array}$ \\
\hline & $\begin{array}{c}\dot{W}_{P(c w)}=\dot{m}_{c w}\left(h_{14}-h_{13}\right) \\
\eta_{P(c w)}=\frac{\left(h_{14 s}-h_{13}\right)}{\left(h_{14}-h_{13}\right)}\end{array}$ & $\begin{array}{c}\dot{W}_{P(c w), r e v}=\dot{m}_{c w}\left(\psi_{14}-\psi_{13}\right) \\
\dot{E}_{P(c w), D}=\dot{W}_{P(c w)}-\dot{W}_{P(c w), r e v} \\
\varepsilon_{P(c w)}=\frac{\dot{W}_{P(c w), r e v}}{\dot{W}_{P(c w)}}\end{array}$ \\
\hline
\end{tabular}
flow is assumed as steady state. The room temperature (dead state temperature) is assumed as $18^{\circ} \mathrm{C}$.

Table 3. Energy and exergy analysis equations of the components of rORC [55-58]. 


\subsection{Working Fluid of the rORC}

Selection of the working fluid for an organic Rankine cycle is a critical step to evaluate the best performing and most feasible system because unlike steam cycles, organic Rankine cycles can work with various hydrocarbon-based fluids. Therefore, the fluid selection criteria should be stated and considered precisely. One of the most important selection criteria for the working fluid is the fluid type. There are three different types of fluids which are dry, isentropic and wet. The saturated vapour line of the dry type fluids has a positive slope, while the wet type has a negative slope and the isentropic type fluids have a zero slope.

The main reason why the fluid type is important is that it is effective in determining the phase of the fluid at the turbine outlet. After the extraction, the turbine outlet phase of the wet type fluids can be a mixture of the liquid-vapour whereas the turbine outlet phase of the isentropic and dry type fluids are mostly in the vapour phase. Moreover, the selected working fluid for a regenerative ORC should be in dry or isentropic type because the turbine outlet temperature of the wet type fluid used in the ORC is generally below or near the pump outlet temperature. Besides the type of the fluid, the thermodynamic properties of a fluid are also crucial to select convenient fluids for existing waste heat source temperature. For these reasons, an isentropic type fluid (R245fa) is selected as a working fluid instead of a wet type fluid (water), the saturation curve of which are given in Figure 3. The mostly considered thermodynamic properties of the R245fa and water are given in Table 4.

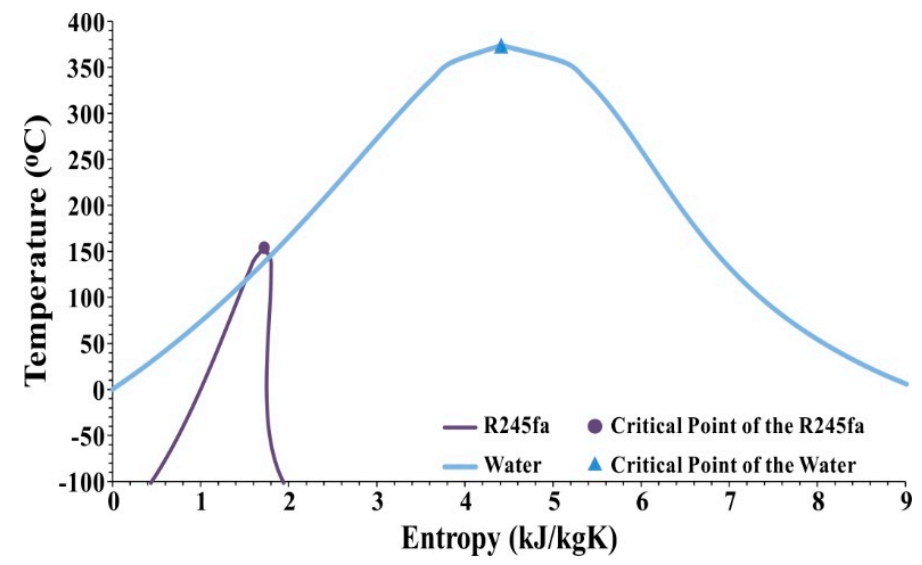

Figure 3. The schematic representation of the rORC assisted CHP engine system.

Table 4. Comparison of the thermodynamic properties of the R245fa and water [59].

\begin{tabular}{cccc}
\hline Parameter & R245fa & Water & Unit \\
\hline Fluid type (chemical basis) & organic & inorganic & - \\
Fluid type (thermodynamic basis) & isentropic & wet & - \\
Boiling point * & 14.81 & 99.60 & ${ }^{\circ} \mathrm{C}$ \\
Critical temperature & 154.01 & 373.94 & ${ }^{\circ} \mathrm{C}$ \\
Critical Pressure & 36.51 & 220.64 & $\mathrm{bar}$ \\
Maximum temperature & 166.85 & 2000 & ${ }^{\circ} \mathrm{C}$ \\
Enthalpy of evaporation * & 196.23 & 2257.50 & $\mathrm{~kJ} / \mathrm{kg}$ \\
\hline
\end{tabular}

* At 1 bar pressure.

The maximum temperature of an organic-based working fluid must be considered strictly. Because the chemical composition of the organic-based working fluids deteriorates above the maximum temperature $[60,61]$. Therefore, during the present study, the system is simulated and optimised for a maximum temperature of $166^{\circ} \mathrm{C}$ which is the maximum temperature of the R245fa. 


\section{Results and Discussion}

\subsection{Subcritical rORC}

The turbine inlet pressure of a subcritical ORC is below the critical pressure. The subcritical rORC is designed for a varying pressure from 4 bar to 30 bar and a temperature from $56{ }^{\circ} \mathrm{C}$ to $166^{\circ} \mathrm{C}$. The saturated vapour temperature is selected as minimum turbine inlet temperature for each pressure value. During the simulation, the maximum temperature of the $\mathrm{R} 245 \mathrm{fa}\left(166^{\circ} \mathrm{C}\right)$ is chosen as the maximum turbine inlet temperature. Because chemical deteriorations occur above the maximum temperature of an organic-based hydrocarbon fluid [60,61]. The change in net power production, mass flow rate, exchanged heat in the regenerator, total pump power consumption, thermal efficiency and exergy efficiency according to varying turbine inlet temperature and pressure of the subcritical rORC is shown in Figure 4.
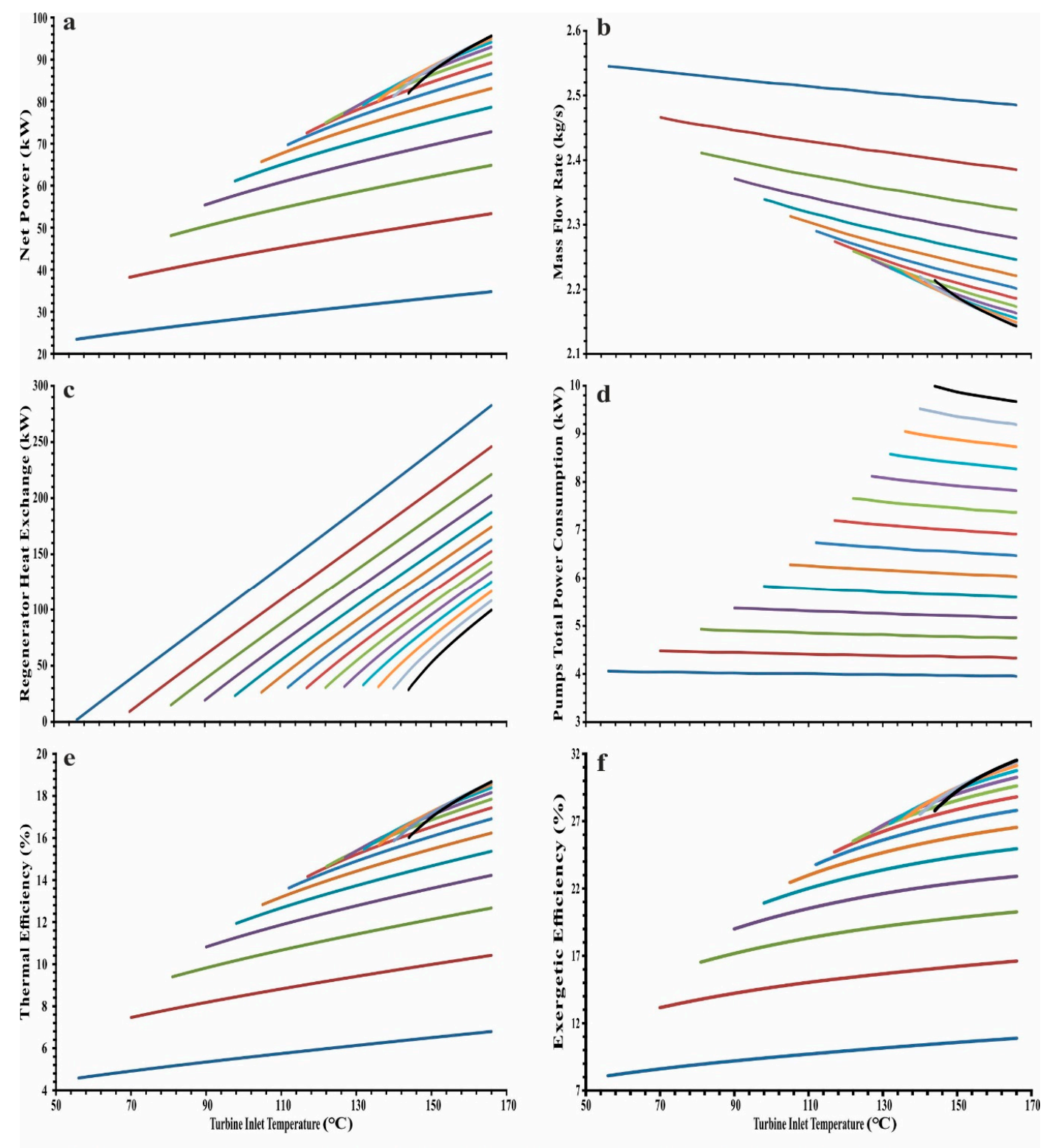

${ }^{4 \mathrm{bar}}-6 \mathrm{bar}-8 \mathrm{bar}-10 \mathrm{bar}-12 \mathrm{bar}-14 \mathrm{bar}-16 \mathrm{bar}-18 \mathrm{bar}-20 \mathrm{bar}-22 \mathrm{bar}-24 \mathrm{bar}-26 \mathrm{bar}-28 \mathrm{bar}-30 \mathrm{bar}$

Figure 4. The change in net power production (a); mass flow rate (b); exchanged heat in the regenerator (c); total pump power consumption (d); thermal efficiency (e) and exergy efficiency (f) according to varying turbine inlet temperature and pressure of the subcritical rORC. 
At constant turbine inlet pressure the net power production, exchanged heat in the regenerator, thermal and exergy efficiencies of the subcritical rORC consistently increase with increasing turbine inlet temperature, while the mass flow rate and total pump power consumption continuously decrease with increasing temperature. However, when the net power production, exchanged heat in the regenerator, thermal and exergy efficiencies are evaluated for varying pressure and temperature, two different trends are seen. In the first trend, up to turbine inlet pressure of 20 bar, the system performance shows a steady increase with increasing temperature at constant pressure.

In the second trend where the overlapping among the lines starts, between the turbine inlet pressure of 20 bar and 30 bar, the performance of the rORC becomes worse than the previous line at the starting temperature (saturated vapour temperature) and then the system performance improves rapidly with increasing temperature. In this trend, at constant pressure with rising temperature, there is a considerable performance increase between the starting and ending points. The main effect of the turbine inlet temperature and pressure combination is seen clearly in this trend. At high pressure, when the turbine inlet temperature is selected near to the saturation temperature, performance results of the system can be worse than the performance values at lower pressures. For instance, the net power production, thermal efficiency and exergetic efficiency of the subcritical rORC at 20 bar $145^{\circ} \mathrm{C}$ is calculated as $84.55 \mathrm{~kW}, 16.52 \%$ and $28.13 \%$ while they are found as $82.97 \mathrm{~kW}, 16.21 \%$ and $28.07 \%$ at 30 bar and $145^{\circ} \mathrm{C}$, respectively. This occurs because of that, as seen in Figure 5, at constant pressure the regenerated heat amount is increased with increasing temperature, which meant that the regenerator effectiveness rises with increasing turbine outlet temperature.
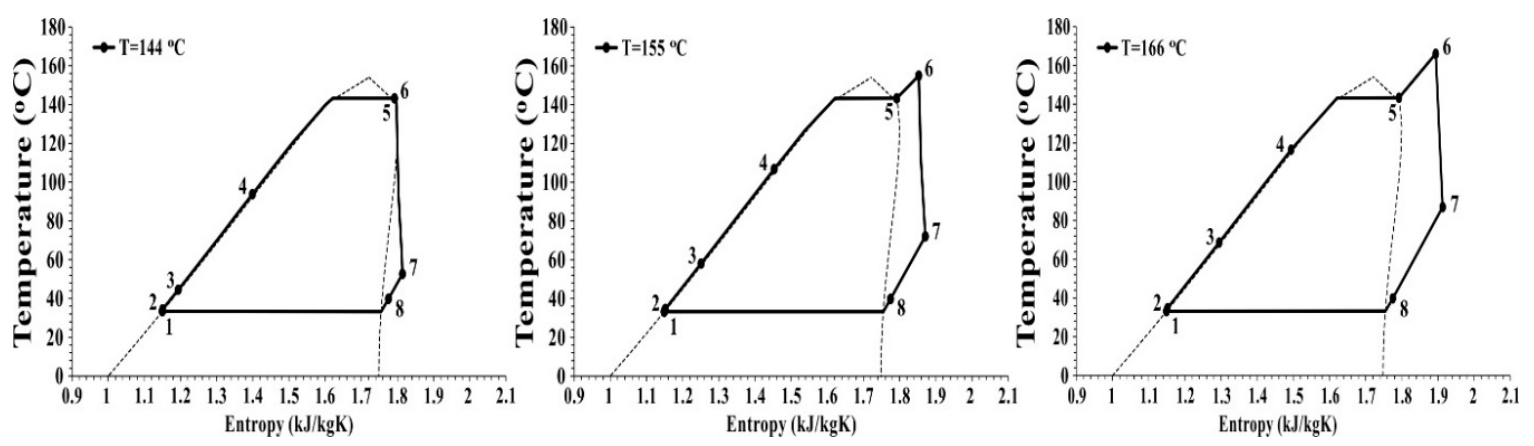

Figure 5. The temperature and entropy (T-s) change of the rORC at constant pressure (30 bar) and varying temperatures $\left(144^{\circ} \mathrm{C}, 155^{\circ} \mathrm{C}\right.$ and $\left.166^{\circ} \mathrm{C}\right)$.

Moreover, as seen in Figure 4c, the transferred heat amount in the regenerator decreases with rising turbine inlet pressure. The main reason for the decrease is that, at constant turbine inlet temperature, the turbine outlet temperature rises with increasing turbine inlet pressure (Figure 6).
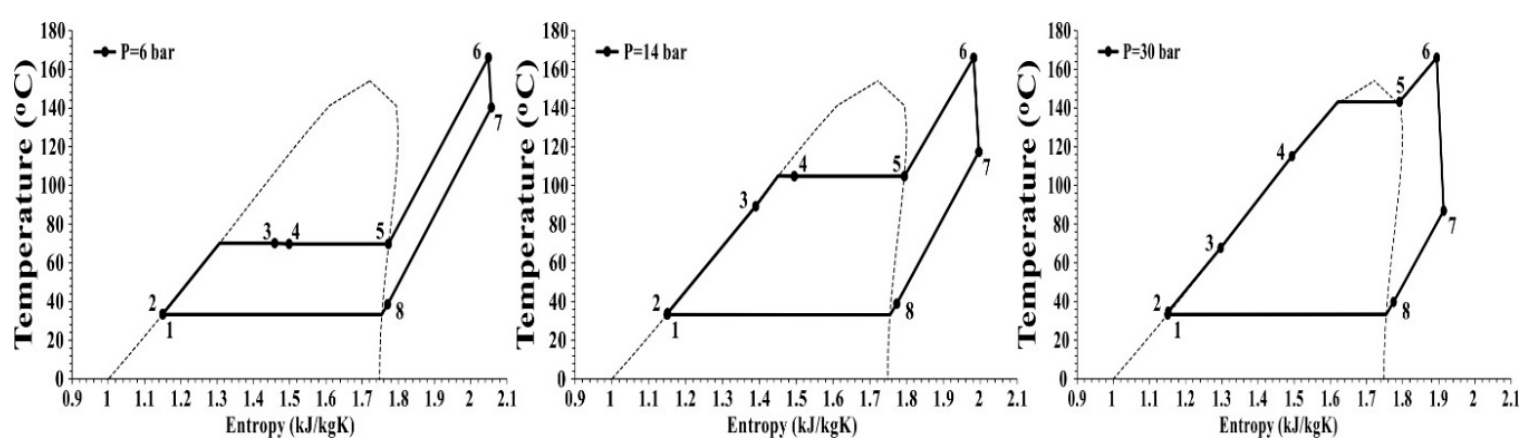

Figure 6. The temperature and entropy (T-s) change of the subcritical rORC at a constant temperature of $166^{\circ} \mathrm{C}$ and varying pressure of 6 bar, 14 bar and 30 bar. 
When all the results obtained from the system for varying turbine inlet temperature and pressure is evaluated together, it is clearly seen that the optimum working performance parameters like turbine inlet temperature and pressure should be selected precisely to get the maximum energy. The net power production, thermal and exergy efficiencies of the best performed rORC is calculated as $95.59 \mathrm{~kW}$, $18.67 \%$ and $31.53 \%$ at turbine inlet temperature and pressure of 30 bar $166^{\circ} \mathrm{C}$, where the mass flow rate and total pump power consumption is found as $2.14 \mathrm{~kg} / \mathrm{s}$ and $9.67 \mathrm{~kW}$, respectively. There are many studies that support the results of the present paper. Chatzopoulou and Markides thermodynamically optimized an ORC-assisted internal combustion engine using R245fa. As a result of the optimization, thermal and exergy efficiencies of the ORC was calculated as $14 \%$ and $33 \%$, respectively [62]. In the present study, at the same turbine inlet temperature and pressure, the net power production per mass flow rate, thermal and exergy efficiencies were calculated as $36.25 \mathrm{~kJ} / \mathrm{kg}, 15.78 \%$ and $27.17 \%$. Zhang et al. performed the performance analysis of a rORC which used pure fluids and azeotropic mixtures as working fluids. As a result of the study, the thermal and exergy efficiencies of the R245fa used subcritical rORC is calculated as $10.54 \%$ and $22.85 \%$ at 12 bar $404 \mathrm{~K}$, respectively [63]. The present study shows similar thermal and exergetic efficiencies results of $13.73 \%$ and $23.38 \%$ at 12 bar $404 \mathrm{~K}$. On the other hand, $\mathrm{Xi}$ et al. studied the parametric optimisation of a single-stage rORC under subcritical conditions and they found the net power production per mass flow rate, thermal and exergy efficiencies as $28.38 \mathrm{~kJ} / \mathrm{kg}, 13.41 \%$ and $50.49 \%$ at 20 bar $135^{\circ} \mathrm{C}$, respectively [64]. However, when the studies in literature are analysed together with those of the present paper, it is thought that the difference between thermal efficiency and exergy efficiency should not be this large.

\subsection{Supercritical rORC}

The turbine inlet pressure of a supercritical ORC is above the critical pressure. In order to describe the differences between subcritical and supercritical rORC and to reveal the cross-over from the subcritical to the supercritical state, the turbine inlet pressure of the rORC is started from a subcritical level (30 bar). Furthermore, the lowest turbine inlet temperature of the designed rORC at constant pressure is accepted as the saturation temperature. Since the chemical deterioration is seen in the chemical structure of the working fluid after the maximum temperature, the highest temperature of the system at constant pressure is assumed as $166^{\circ} \mathrm{C}$, which is equal to the maximal temperature of the $\mathrm{R} 245 \mathrm{fa}[60,61]$. The change in net power production, mass flow rate, exchanged heat in the regenerator, total pump power consumption, thermal efficiency and exergy efficiency according to varying turbine inlet temperature and pressure of the supercritical rORC is given in Figure 7.

In Figure 7, the performance of the subcritical and supercritical rORCs are given together. The rORC is working under subcritical conditions up to 36.51 bar turbine inlet pressure. Above 36.51 bar, the system starts to work under supercritical conditions. At constant pressure with increasing temperature, an increase is seen in the net power production, exchanged heat in the regenerator, thermal and exergy efficiencies while a decrease is seen the mass flow rate and total pump power consumption. However, the rORC shows opposite performance at a constant temperature with rising pressure. The best performing supercritical rORC cycle is obtained at a turbine inlet pressure and temperature of 38 bar and $166^{\circ} \mathrm{C}$.

The net power production, thermal and exergetic efficiencies of the supercritical rORC is calculated as $92.29 \mathrm{~kW}, 18.03 \%$ and $30.82 \%$ at 38 bar and $166{ }^{\circ} \mathrm{C}$. Above the 38 bar turbine inlet pressure, the performance of the rORC is diminished. The main reason for the performance reduction above the 38 bar is that above this pressure the turbine outlet temperature is so near to the condenser outlet temperature which reduces the amount of heat transferred in the regenerator (Figure 8).

Moreover, above 36 bar, the phase of the working fluid in the turbine becomes a saturated liquid and vapour mixture at low temperatures. Therefore, in the turbine, the liquid droplets occur which reduces the turbine performance and consequently decreases the performance of the rORC.

In many studies, similar results were obtained. Fernández et al. analysed a supercritical rORC using siloxanes as working fluid and as a result of the study, the thermal efficiency range varied 
from $15.1 \%$ to $15.9 \%$ for D4 type siloxanes, from $19.4 \%$ to $22 \%$ for MM type siloxanes [65]. Although decomposition and deterioration in the chemical structure of the hydrocarbon-based working fluid is seen above the maximum temperature, Wang et al. studied a regenerative supercritical organic Rankine cycle for a turbine inlet temperature varying between $200^{\circ} \mathrm{C}$ and $300{ }^{\circ} \mathrm{C}$, which values are much higher than the maximum temperature of the R245fa [66].
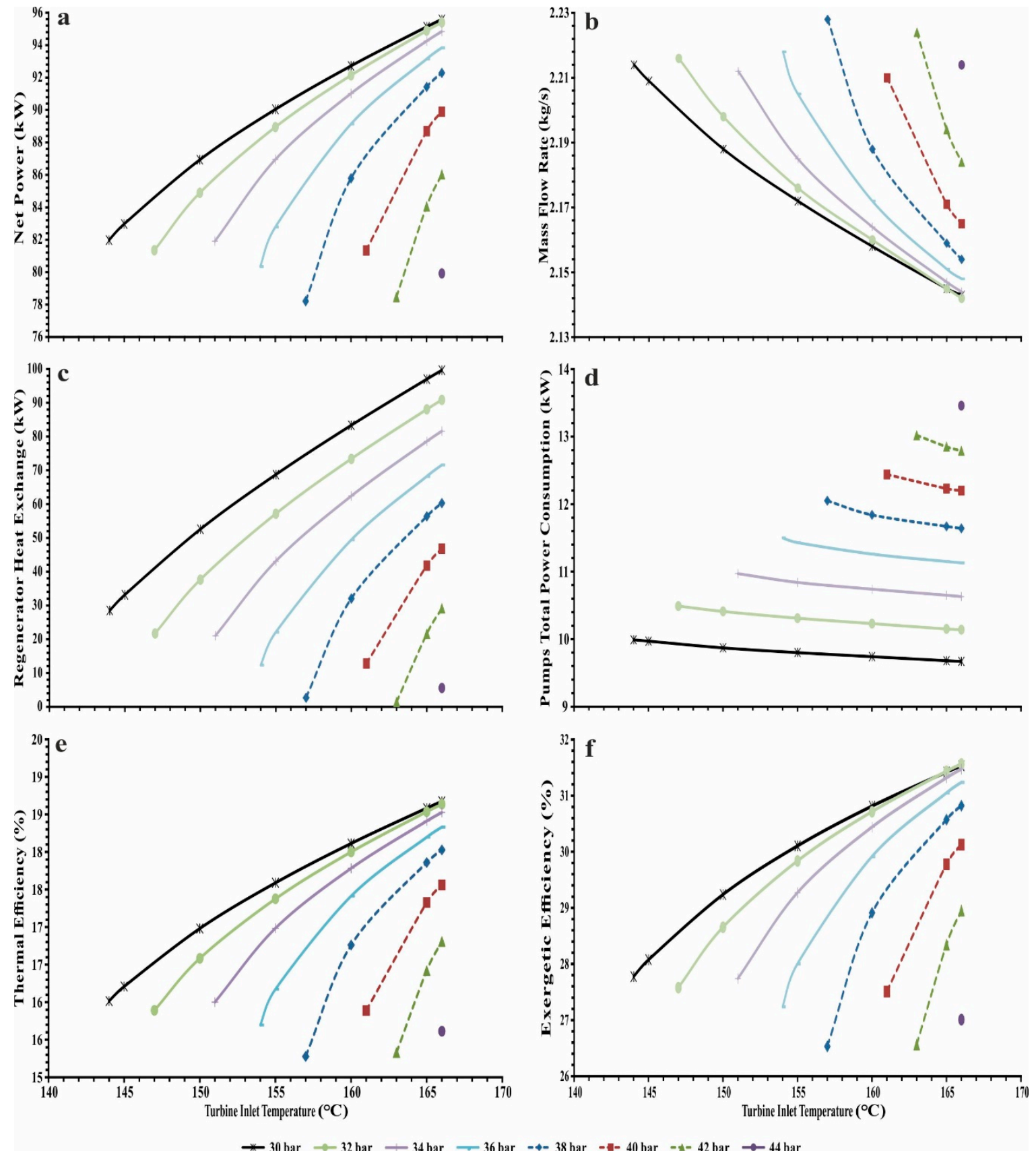

Figure 7. The change in net power production (a); mass flow rate (b); exchanged heat in the regenerator (c); total pump power consumption (d); thermal efficiency (e) and exergy efficiency (f) according to varying turbine inlet temperature and pressure of the supercritical rORC. 

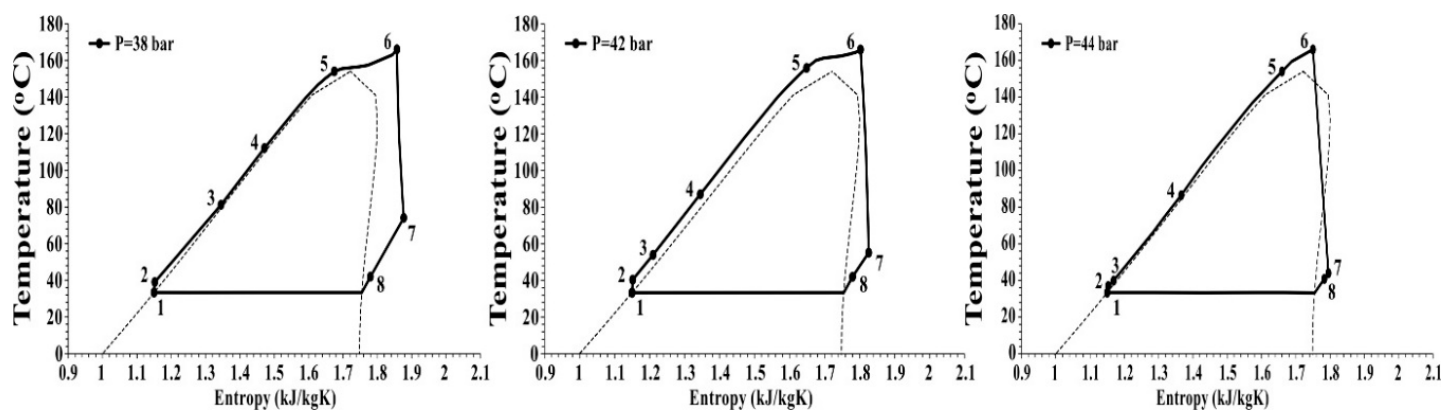

Figure 8. The temperature and entropy (T-s) change of the supercritical rORC at a constant temperature of $166^{\circ} \mathrm{C}$ and varying pressure of 38 bar, 42 bar and 44 bar.

\subsection{Effect of the Regenerator}

This study aims to demonstrate the effect of the regenerator on the system performance as well as the parametric optimization of the rORC. Sometimes, small improvements applied to the system can give better performance results than radical changes [67]. Therefore, in order to decide the best design and cycle condition, different types of organic Rankine cycle designs are studied in this paper and in the previous paper [52]. In the concept of the present paper, a subcritical and supercritical rORC is designed and parametrically optimised. In the previous paper, the designing and parametric optimisation procedure are applied to a simple subcritical and supercritical ORC [52]. Comparison of the thermal efficiencies of the simple ORC evaluated from the previous paper [52] and rORC evaluated from the present paper is seen in Figure 9. When the thermal efficiency of the rORC is compared with the thermal efficiency of the simple ORC, it is seen that thermal efficiency lines of the simple ORC are close to each other at constant pressure with rising temperature. This closeness among the lines of the simples ORC shows that turbine inlet pressure is more effective on cycle efficiency than the turbine inlet temperature. On the other hand, at constant pressure with rising temperature, there is a considerable difference among the thermal efficiency lines of the rORC.

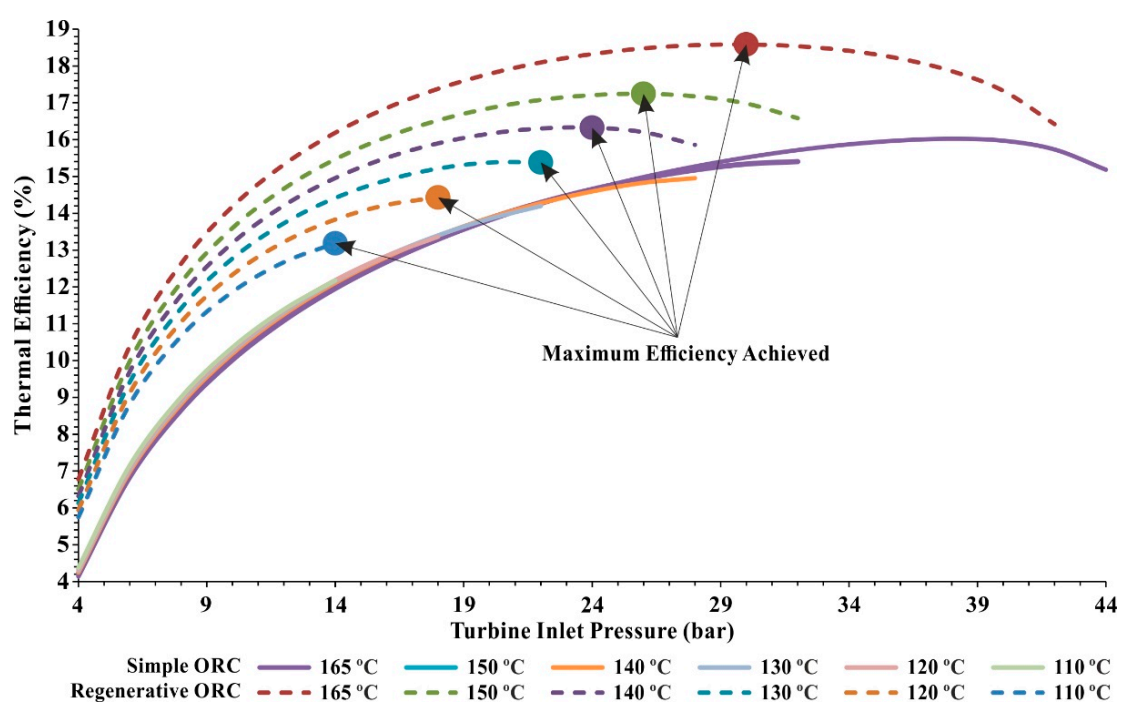

Figure 9. Comparison of the thermal efficiencies of the simple organic Rankine cycle (ORC) and regenerative organic Rankine cycle (rORC).

Different types of ORC configurations (simple, regenerative, subcritical or supercritical) has many advantageous and disadvantageous to each other. For instance, the investment cost of a supercritical ORC is higher than that of a subcritical one $[12,68]$ Moreover, compared with the subcritical ORC, the supercritical ORC has a higher turbine inlet pressure which affects the safety as well as investment cost $[69,70]$. When the ORC systems are compared in term of the regenerative 
and simple (non-regenerative) cycle, there are many studies which prove the superiority of the performance of rORC over simple ORC [71-76]. In this study, the best performed subcritical and supercritical rORC is evaluated at a turbine inlet temperature and pressure of 30 bar $166{ }^{\circ} \mathrm{C}$ and $38 \mathrm{bar}, 166^{\circ} \mathrm{C}$, respectively. The net power production, thermal and exergetic efficiencies are calculated as $95.59 \mathrm{~kW}, 18.67 \%$ and $31.53 \%$ for the subcritical rORC and $92.29 \mathrm{~kW}, 18.03 \%$ and $30.82 \%$ for the supercritical rORC, respectively. In other respects, as a result of the calculations made for simple ORC in the previous paper, the net power production, thermal and exergetic efficiencies are calculated as $79.23 \mathrm{~kW}, 15.51 \%$ and $27.20 \%$ for the subcritical ORC and $81.52 \mathrm{~kW}, 15.93 \%$ and $27.76 \%$ for the supercritical ORC, respectively [52]. As a conclusion, when cycle performance, investment cost, safety considered together, subcritical rORC can be selected as an optimum cycle rather than supercritical rORC, subcritical ORC and supercritical ORC.

In addition to all these considerations, a considerable limitation in turbine inlet temperature and pressure ranges is seen for rORC. When compared to the previous study, due to maximal temperature limitation and effect of the regenerator, the operating range of the rORC is even lower. This limitation is especially seen in the supercritical rORC results. In the previous study, the supercritical ORC runs for a wide range of turbine inlet temperatures and pressures. However, in the present study, a considerable decrease in working ranges are seen due to the regenerator. Therefore, at the turbine inlet pressure of $44 \mathrm{bar}$, the rORC is working only for one turbine inlet temperature point $\left(166^{\circ} \mathrm{C}\right)$.

\subsection{Comparison of the Exergy Analysis of the Subcritical and Supercritical rORC}

As a result of the parametric optimisation, the best performed cycle is evaluated at 30 bar $166{ }^{\circ} \mathrm{C}$ for the subcritical rORC and 38 bar $166^{\circ} \mathrm{C}$ for the supercritical rORC. However, the maximal temperature of the selected working fluid ( $\mathrm{R} 245 \mathrm{fa}$ ) is $166.85^{\circ} \mathrm{C}$ which is almost equal to the turbine inlet temperature of the best-performing cycle. The working fluids of the rORC are organic-based hydrocarbon refrigerants. The chemical composition of the organic-based hydrocarbon refrigerants deteriorates above the maximum temperature $[60,61]$. Therefore, in order to protect the chemical structure of the fluid and keep in safe the working condition of the $\mathrm{rORC}$, the best performing turbine inlet temperature is accepted as $165^{\circ} \mathrm{C}$ for both subcritical and supercritical rORC. By considering this acceptance, the thermodynamic flow parameters recorded for the rORC pipes numbered in Figure 2 at subcritical $\left(30\right.$ bar $\left.165^{\circ} \mathrm{C}\right)$ and supercritical $\left(38\right.$ bar $\left.165^{\circ} \mathrm{C}\right)$ conditions are given in Table 5 .

Table 5. The flow parameters recorded for the rORC at subcritical $\left(30\right.$ bar $\left.165^{\circ} \mathrm{C}\right)$ and supercritical (38 bar $165^{\circ} \mathrm{C}$ ) conditions.

\begin{tabular}{ccccccccc}
\hline & \multicolumn{7}{c}{ Subcritical $\mathbf{( 3 0}$ bar, $\left.\mathbf{1 6 5}{ }^{\circ} \mathbf{C}\right)$} \\
\hline Pipe No ${ }^{*}$ & $\mathrm{P}$ & $\mathrm{T}$ & $h$ & $\dot{m}$ & $\rho$ & $\mathrm{s}$ & $\psi$ & $H=\dot{m} h$ \\
\hline & $\mathrm{bar}$ & ${ }^{\circ} \mathrm{C}$ & $\mathrm{kJ} / \mathrm{kg}$ & $\mathrm{kg} / \mathrm{s}$ & $\mathrm{kg} / \mathrm{m}^{3}$ & $\mathrm{~kJ} / \mathrm{kgK}$ & $\mathrm{kJ} / \mathrm{kg}$ & $\mathrm{kW}$ \\
\hline 1 & 2.00 & 33.35 & 243.587 & 2.15 & 1315.5 & 1.1501 & 2.5365 & 522.57 \\
2 & 30.15 & 34.78 & 246.254 & 2.15 & 1321.2 & 1.1518 & 4.6995 & 528.30 \\
3 & 30.10 & 67.71 & 291.471 & 2.15 & 1225.5 & 1.2913 & 9.3159 & 625.30 \\
4 & 30.05 & 115.71 & 364.131 & 2.15 & 1042.1 & 1.4904 & 24.0025 & 781.18 \\
5 & 30.05 & 143.29 & 487.900 & 2.15 & 232.3 & 1.7917 & 60.0493 & 1046.71 \\
6 & 30.00 & 165.00 & 530.077 & 2.15 & 163.2 & 1.8907 & 73.3897 & 1137.19 \\
7 & 2.00 & 85.64 & 480.407 & 2.15 & 9.3 & 1.9098 & 18.1715 & 1030.63 \\
8 & 2.00 & 39.78 & 435.191 & 2.15 & 11.1 & 1.7750 & 12.1937 & 933.63 \\
9 & 1.00 & 450.00 & 465.445 & 1.63 & 0.5 & 7.7817 & 173.4936 & 758.68 \\
10 & 1.00 & 398.35 & 409.934 & 1.63 & 0.5 & 7.7023 & 141.0851 & 668.19 \\
11 & 1.00 & 243.29 & 247.034 & 1.63 & 0.7 & 7.4267 & 58.4350 & 402.67 \\
12 & 1.00 & 150.00 & 151.403 & 1.63 & 0.8 & 7.2228 & 22.1667 & 246.79 \\
13 & 1.00 & 25.00 & 104.928 & 19.71 & 997.0 & 0.3672 & 0.3452 & 2067.90 \\
14 & 2.00 & 25.01 & 105.053 & 19.71 & 997.1 & 0.3673 & 0.4460 & 2070.37 \\
15 & 1.50 & 30.01 & 125.911 & 19.71 & 995.7 & 0.4369 & 1.0566 & 2481.42 \\
\hline
\end{tabular}


Table 5. Cont.

\begin{tabular}{ccccccccc}
\hline \multicolumn{7}{c}{ Supercritical $\mathbf{( 3 8}$ bar, $\left.\mathbf{1 6 5} \mathbf{~}^{\circ} \mathbf{C}\right)$} \\
\hline Pipe $\mathrm{No}^{*}$ & $\mathrm{P}$ & $\mathrm{T}$ & $h$ & $\dot{m}$ & $\rho$ & $\mathrm{s}$ & $\psi$ & $H=\dot{m} h$ \\
\hline & $\mathrm{bar}$ & ${ }^{\circ} \mathrm{C}$ & $\mathrm{kJ} / \mathrm{kg}$ & $\mathrm{kg} / \mathrm{s}$ & $\mathrm{kg} / \mathrm{m}^{3}$ & $\mathrm{~kJ} / \mathrm{kgK}$ & $\mathrm{kJ} / \mathrm{kg}$ & $\mathrm{kW}$ \\
\hline 1 & 2.00 & 33.35 & 243.587 & 2.16 & 1315.5 & 1.1501 & 2.5365 & 525.84 \\
2 & 38.15 & 35.17 & 247.010 & 2.16 & 1322.8 & 1.1523 & 5.3129 & 533.23 \\
3 & 38.10 & 54.49 & 273.132 & 2.16 & 1269.1 & 1.2345 & 7.5100 & 589.62 \\
4 & 38.05 & 104.57 & 345.901 & 2.16 & 1101.2 & 1.4409 & 20.1850 & 746.71 \\
5 & 38.05 & 154.01 & 440.548 & 2.16 & 726.6 & 1.6748 & 46.7240 & 951.03 \\
6 & 38.00 & 165.00 & 510.254 & 2.16 & 268.2 & 1.8366 & 69.3346 & 1101.51 \\
7 & 2.00 & 66.82 & 461.703 & 2.16 & 9.9 & 1.8563 & 15.0565 & 996.70 \\
8 & 2.00 & 40.17 & 435.581 & 2.16 & 11.0 & 1.7763 & 12.2211 & 940.31 \\
9 & 1.00 & 450.00 & 465.445 & 1.63 & 0.5 & 7.7817 & 173.4936 & 758.68 \\
10 & 1.00 & 363.77 & 373.128 & 1.63 & 0.5 & 7.6460 & 120.6624 & 608.20 \\
11 & 1.00 & 244.01 & 247.778 & 1.63 & 0.7 & 7.4281 & 58.7598 & 403.88 \\
12 & 1.00 & 150.00 & 151.404 & 1.63 & 0.8 & 7.2228 & 22.1669 & 246.79 \\
13 & 1.00 & 25.00 & 104.928 & 19.87 & 997.0 & 0.3672 & 0.3452 & 2085.07 \\
14 & 2.00 & 25.01 & 105.053 & 19.87 & 997.1 & 0.3673 & 0.4460 & 2087.56 \\
15 & 1.50 & 30.01 & 125.911 & 19.87 & 995.7 & 0.4369 & 1.0566 & 2502.03 \\
\hline
\end{tabular}

* The numbers given in Figure 2 are used as pipe number

The data evaluated from the pipes are used to calculate the exergy flow and exergetic efficiency of each component. By using the equations given above, the exergy inlet, exergy outlet and exergetic efficiencies of each component of subcritical and supercritical rORC are found which are shown in Figure 10.
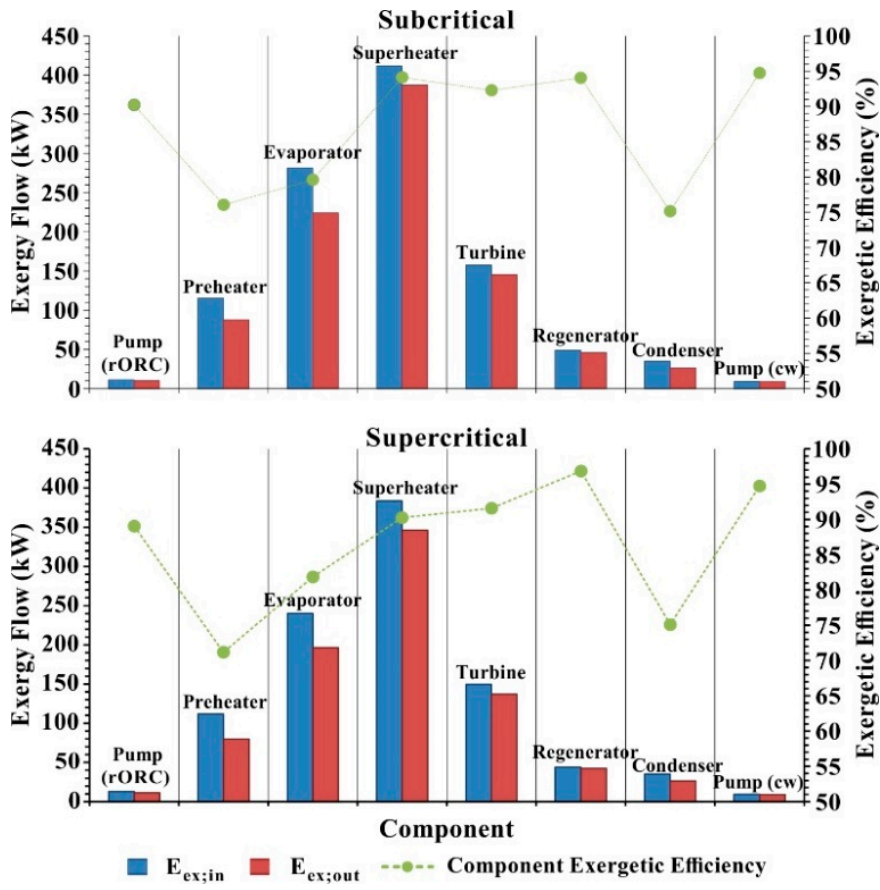

Figure 10. The exergy inlet, exergy outlet and exergetic efficiencies of each component of subcritical and supercritical rORC.

The columns given in Figure 10 represent the exergy flow while the green line represents the component exergetic efficiency. For both subcritical and supercritical rORC, the exergy inlet and outlet are calculated in the superheater as maximum and in the pump $(\mathrm{cw})$ as a minimum. As for component exergetic efficiency, the maximum and minimum component exergetic efficiency is found in the pump 
$(\mathrm{cw})$ and condenser for the subcritical rORC and in the regenerator and preheater for the supercritical rORC, respectively. The maximum exergy inlet and exergy outlet are determined as $411.62 \mathrm{~kW}$ and $387.41 \mathrm{~kW}$ in the superheater component of the subcritical rORC and $383.66 \mathrm{~kW}$ and $346.36 \mathrm{~kW}$ in the superheater component of the supercritical rORC. The highest and lowest component exergetic efficiencies are found as $94.74 \%$ in the pump (cw) and $75.15 \%$ in the condenser for the subcritical rORC and $96.87 \%$ in the regenerator and $71.17 \%$ in preheater for the supercritical rORC. As seen from the general exergy balance equation given above, the differences between the inlet and outlet exergy equal to the exergy destruction. The exergy destruction rate of each component of the subcritical and supercritical rORC is given in Figure 11. The maximum exergy destruction is calculated as $57.39 \mathrm{~kW}$ for subcritical rORC and $43.61 \mathrm{~kW}$ for supercritical rORC in the evaporator. The minimum exergy destruction is found as $0.48 \mathrm{~kW}$ for subcritical rORC and $0.49 \mathrm{~kW}$ for supercritical rORC in the pump (cw).

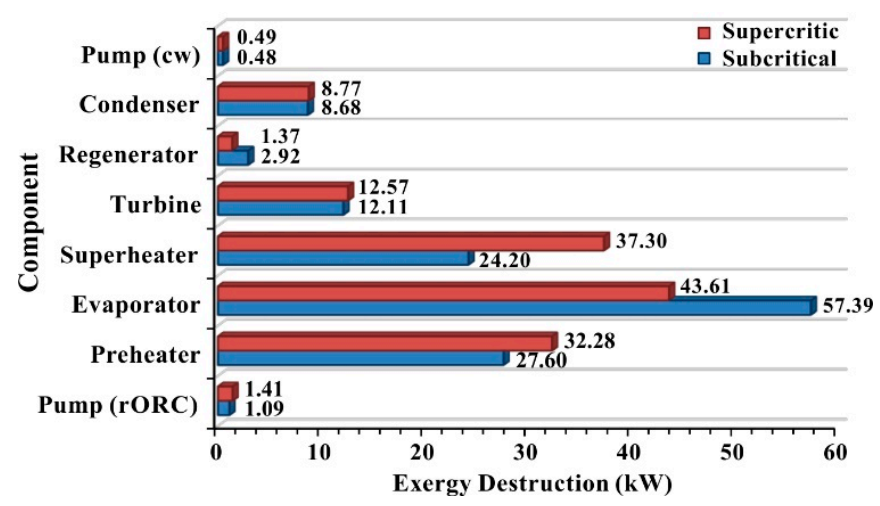

Figure 11. The exergy destruction rate of each component of the subcritical and supercritical rORC.

When the overall system parameters evaluated form the energetic and exergetic analysis of the rORC is considered together, the overall thermal and exergetic efficiencies are calculated as $19.17 \%$ and $32.41 \%$ for the subcritical rORC (at 30 bar, $165{ }^{\circ} \mathrm{C}$ ) and $18.50 \%$ and $31.67 \%$ for the supercritical rORC (at $38 \mathrm{bar}, 165^{\circ} \mathrm{C}$ ). Abam et al. compared the exergy-based performance analysis of a subcritical rORC for varying turbine inlet pressure range from 20 bar to 30 bar. As a result of the study, the maximum component exergy efficiency and component exergy destruction were calculated in evaporator and pump, respectively. Moreover, the overall exergy efficiency of the subcritical rORC using R245fa as working fluid is found between 30\% and 35\% [77]. Energy and exergy-based analysis of a rORC assisted to a combined heat and power plant is studied by Anvari et al. They found that the component exergy destruction was maximum in evaporator and minimum in the pumps [78]. The results of the studies are in line with the result of the present study.

\section{Conclusions}

In the concept of the present paper, firstly, a rORC was designed and parametrically optimised to evaluate the best-performing cycle condition to recover exhaust gas waste heat from a CHP engine. Then, to show the effect of regenerator on system performance, the parameters evaluated from the best performing subcritical and supercritical rORC was compared with the results of the previous paper which includes parametric optimisation of a simple subcritical and supercritical ORC. Finally, the exergetic analyses of the components and overall rORC was performed.

In the performance analysis of the subcritical rORC; at the constant turbine inlet pressure with rising temperature, an increase was observed in the net power production, exchanged heat in the regenerator, thermal and exergy efficiencies, while a continuous decrease was seen in the mass flow rate and the total pump power consumption. On the other hand, with varying turbine inlet temperature and pressure; the net power production, thermal and exergetic efficiencies continuously increased up to a turbine inlet pressure of 20 bar. Between the turbine inlet pressure of $20 \mathrm{bar}$ and $30 \mathrm{bar}$, the net power production, thermal and exergy efficiencies became worse than the previous line at the starting 
temperature (saturated vapour temperature) and then the results rapidly increased with rising turbine inlet temperature. The main reason for dramatically increasing from worse results to better seen as the rapidly increasing regenerated heat amount. Between the turbine inlet pressure of 30 bar and 36 bar, the net power production, thermal and exergy efficiencies decreased with rising turbine inlet pressure. The reason for the performance decline is seen as the closeness of the turbine inlet temperature and saturated vapour temperature at this pressure ranges.

In the performance analysis of the supercritical rORC; the net power production, exchanged heat in the regenerator, thermal and exergy efficiencies showed rising results with increasing temperature at constant pressure, but, the performance of the rORC showed a decreasing result with rising pressure at constant temperature. The net power production, thermal and exergetic efficiencies are found as $92.29 \mathrm{~kW}, 18.03 \%$ and $30.82 \%$ for the best performing supercritical rORC at turbine inlet temperature and pressure of $38 \mathrm{bar}, 166^{\circ} \mathrm{C}$. In the case of the subcritical rORC, the net power production, thermal and exergetic efficiencies are calculated as $95.59 \mathrm{~kW}, 18.67 \%$ and $31.53 \%$ for the best performing subcritical rORC at a turbine inlet temperature and pressure of $30 \mathrm{bar} 166^{\circ} \mathrm{C}$. When the result of the previous study is considered [52], it is clearly seen that the subcritical rORC shows the best performance, so by using the subcritical rORC, the disadvantages of the using simple ORC (low performance) and supercritical cycle (safety, investment) can be eliminated, while improving system performance.

Despite the positive system performance results, the use of regenerators in the ORC creates restrictive effects on working pressure and temperature intervals, especially in supercritical conditions. At constant pressure, the turbine inlet temperature range of the rORC is narrower than the simple ORC. Moreover, unlike the simple ORC, the upper pressure of the rORC is also limited. While the simple ORC can operate in temperature between $155^{\circ} \mathrm{C}$ and $166^{\circ} \mathrm{C}$ at 46 bar turbine inlet pressure, the rORC could not work at 46 bar turbine inlet pressure due to the maximal temperature limitation and effect of the regenerator. The rORC can only be worked a turbine inlet pressure of 44 bar where the rORC is only working at a turbine inlet temperature of $166^{\circ} \mathrm{C}$. In spite of the restrictive effect of the regenerator, the rORC systems showed better performance results than simple ORC for both subcritical and supercritical conditions.

As seen from Figure 9, the thermal efficiency reached its maximum value at certain pressures while the increase in the thermal efficiency continued with the pressure increase at the constant temperature. After the maximum point where the thermal efficiency was the highest, the increase in the pressure caused a decrease in the thermal efficiency. For this reason, considering the turbine inlet pressures where maximum efficiency is obtained depending on the temperature has critical importance in regenerator usage.

In addition, the exergetic analysis of the best performing subcritical and supercritical rORC was performed and the results were compared with each other as well as a simple ORC. Just like the simple ORC, the highest exergy destruction was seen in the evaporator. The overall thermal and exergetic efficiencies are calculated as $19.17 \%$ and $32.41 \%$ for the subcritical rORC and $18.50 \%$ and $31.67 \%$ for the supercritical rORC. On the other hand, in the previous paper, the thermal and exergetic efficiencies of the simple ORC was found as $15.51 \%$ and $27.20 \%$ for the best performing subcritical condition, $15.93 \%$ and $27.76 \%$ for the best performing supercritical condition [52]. When the results of the present and previous paper compared, it is clearly seen that the subcritical regenerative organic Rankine cycle (rORC) has the best performance.

Author Contributions: A.K. decided the designing condition of the system and system limitations; Y.K. and H.Y. designed and simulated the system; H.Y. prepared the graphics; A.K., Y.K. and H.Y. analysed and discussed simulation results in detail; Y.K. and H.Y. wrote the article; A.K. checked the article thoroughly after writing.

Funding: This research received no external funding.

Acknowledgments: Due to the contribution to obtain the required information and data for the study, the authors are thankful to the Tom De Vrieze (from the Vanheede Environment Group), Bruno Vanslambrouck and Martijn van den Broek (from the Ghent University), Marc J. M. Van Wonterghem. The authors are also grateful to the Steag $\mathrm{GmbH}$ for their help in obtaining the EBSILON®Professional (EBSILON) software. 
Conflicts of Interest: The authors declare no conflict of interest.

\section{Abbreviations}

\begin{tabular}{|c|c|}
\hline \multicolumn{2}{|c|}{ Nomenclature } \\
\hline $\mathrm{CHP}$ & combined heat and power \\
\hline $\mathrm{cW}$ & cooling water \\
\hline$\dot{E}_{e x}$ & exergy flow (kW) \\
\hline$h$ & enthalpy (kJ/kg) \\
\hline$H$ & enthalpy flow (kW) \\
\hline$\dot{m}$ & mass flow $(\mathrm{kg} / \mathrm{s})$ \\
\hline $\mathrm{P}$ & pressure (bar) \\
\hline$\dot{Q}$ & heat flow $(\mathrm{kW})$ \\
\hline rORC & regenerative organic Rankine cycle \\
\hline$s$ & entropy $(\mathrm{kJ} / \mathrm{kgK})$ \\
\hline $\mathrm{T}$ & temperature $\left({ }^{\circ} \mathrm{C}\right)$ \\
\hline $\mathrm{T}_{0}$ & ambient temperature $\left({ }^{\circ} \mathrm{C}\right)$ \\
\hline$\dot{W}$ & power $(\mathrm{kW})$ \\
\hline \multicolumn{2}{|c|}{ Greek letters } \\
\hline$\rho$ & density $\left(\mathrm{kg} / \mathrm{m}^{3}\right)$ \\
\hline$\psi$ & specific exergy $(\mathrm{kJ} / \mathrm{kg})$ \\
\hline$\varepsilon$ & exergetic efficiency (\%) \\
\hline$\eta$ & thermal efficiency (\%) \\
\hline \multicolumn{2}{|c|}{ Subscripts } \\
\hline C & condenser \\
\hline$c w$ & cooling water \\
\hline$D$ & destruction \\
\hline E & evaporator \\
\hline exh & exhaust \\
\hline HS & heat transfer surface \\
\hline$i$ & inlet \\
\hline $\max$ & maximum \\
\hline$o$ & outlet \\
\hline$P$ & pump \\
\hline PH & preheater \\
\hline$R$ & regenerator \\
\hline rev & reversible \\
\hline$S H$ & superheater \\
\hline$T$ & turbine \\
\hline
\end{tabular}

\section{References}

1. Kuyumcu, M.E.; Tutumlu, H.; Yumrutaş, R. Performance of a swimming pool heating system by utilizing waste energy rejected from an ice rink with an energy storage tank. Energy Convers. Manag. 2016, 121, 349-357. [CrossRef]

2. Tutumlu, H.; Yumrutaş, R.; Yildirim, M. Investigating thermal performance of an ice rink cooling system with an underground thermal storage tank. Energy Explor. Exploit. 2018, 36, 314-334. [CrossRef]

3. Tanç, B.; Arat, H.T.; Baltacıŏlu, E.; Aydın, K. Overview of the next quarter century vision of hydrogen fuel cell electric vehicles. Int. J. Hydrog. Energy 2018. [CrossRef]

4. Koç, A.; Yağlı, H.; Koç, Y.; Uğurlu, İ. Dünyada ve Türkiye'de Enerji Görünümünün Genel Değerlendirilmesi. Eng. Mach. Mag. 2018, 59, 86-114.

5. Lund, H. Renewable Heating Strategies and their Consequences for Storage and Grid Infrastructures Comparing a Smart Grid to a Smart Energy Systems Approach. Energy 2018, 151, 94-102. [CrossRef] 
6. Mert, İ.; Karakuş, C.; Üneş, F. Estimating the energy production of the wind turbine using artificial neural network. Neural Comput. Appl. 2016, 27, 1231-1244. [CrossRef]

7. Öksel, C.; Koç, A.; Koç, Y.; Yağlı, H. Antakya körfezi deniz üstü rüzgâr enerjisi potansiyel araştirilmasi. Selçuk Üniversitesi Mühendislik Bilim Ve Teknoloji Dergisi 2016, 4, 18-29.

8. Tempesti, D.; Manfrida, G.; Fiaschi, D. Thermodynamic analysis of two micro CHP systems operating with geothermal and solar energy. Appl. Energy 2012, 97, 609-617. [CrossRef]

9. Theo, W.L.; Lim, J.S.; Ho, W.S.; Hashim, H.; Lee, C.T.; Muis, Z.A. Optimisation of oil palm biomass and palm oil mill effluent (POME) utilisation pathway for palm oil mill cluster with consideration of BioCNG distribution network. Energy 2017, 121, 865-883. [CrossRef]

10. Kim, S.; Sung, T.; Kim, K.C. Thermodynamic Performance Analysis of a Biogas-Fuelled Micro-Gas Turbine with a Bottoming Organic Rankine Cycle for Sewage Sludge and Food Waste Treatment Plants. Energies 2016, 10, 275. [CrossRef]

11. Barati, M.R.; Aghbashlo, M.; Ghanavati, H.; Tabatabaei, M.; Sharifi, M.; Javadirad, G.; Dadak, A.; Soufiyan, M.M. Comprehensive exergy analysis of a gas engine-equipped anaerobic digestion plant producing electricity and biofertilizer from organic fraction of municipal solid waste. Energy Convers. Manag. 2017, 151, 753-763. [CrossRef]

12. Dumont, O.; Dickes, R.; De Rosa, M.; Douglas, R.; Lemort, V. Technical and economic optimization of subcritical, wet expansion and transcritical Organic Rankine Cycle (ORC) systems coupled with a biogas power plant. Energy Convers. Manag. 2018, 157, 294-306. [CrossRef]

13. Akgul, D.; Cella, M.A.; Eskicioglu, C. Influences of low-energy input microwave and ultrasonic pretreatments on single-stage and temperature-phased anaerobic digestion (TPAD) of municipal wastewater sludge. Energy 2017, 123, 271-282. [CrossRef]

14. Itodo, I.N.; Agyo, G.E.; Yusuf, P. Performance evaluation of a biogas stove for cooking in Nigeria. J. Energy South. Afr. 2017, 18, 14-18.

15. Hakawati, R.; Smyth, B.M.; McCullough, G.; De Rosa, F.; Rooney, D. What is the most energy efficient route for biogas utilization: Heat, electricity or transport? Appl. Energy 2017, 206, 1076-1087. [CrossRef]

16. Sung, T.; Kim, S.; Kim, K.C. Thermoeconomic analysis of a biogas-fueled micro-gas turbine with a bottoming organic Rankine cycle for a sewage sludge and food waste treatment plant in the Republic of Korea. Appl. Therm. Eng. 2017, 127, 963-974. [CrossRef]

17. Madeira, J.G.F.; Boloy, R.A.M.; Delgado, A.R.S.; Lima, F.R.; Coutinho, E.R.; de Castro Pereira Filho, R. Ecological analysis of hydrogen production via biogas steam reforming from cassava flour processing wastewater. J. Clean. Prod. 2017, 162, 709-716. [CrossRef]

18. Barzegaravval, H.; Hosseini, S.E.; Wahid, M.A.; Saat, A. Effects of fuel composition on the economic performance of biogas-based power generation systems. Appl. Therm. Eng. 2018, 128, 1543-1554. [CrossRef]

19. Liu, W.H.; Hashim, H.; Lim, J.S.; Ho, C.S.; Klemeš, J.J.; Zamhuri, M.I.; Ho, W.S. Techno-Economic Assessment of Different Cooling Systems for Office Buildings in Tropical Large City Considering On-site Biogas Utilization. J. Clean. Prod. 2018, 184, 774-787. [CrossRef]

20. Chatzopoulou, M.A.; Christos, N. Markides Modelling of Advanced Combined Heat and Power Systems in Building Applications. Available online: http:/ /dl.astfe.org/conferences/tfec2017,5303da2e708371c8, 220146de273cf89f.html (accessed on 14 January 2019).

21. Ameri, M.; Mokhtari, H. Simulation of a New Hybrid Solar and Organic Cycle as a Combined Cooling, Heat and Power (CCHP) Unit in Off Design Condition. Environ. Energy Econ. Res. 2017, 1, 183-194.

22. Uris, M.; Linares, J.I.; Arenas, E. Feasibility assessment of an Organic Rankine Cycle (ORC) cogeneration plant (CHP/CCHP) fueled by biomass for a district network in mainland Spain. Energy 2017, 133, 969-985. [CrossRef]

23. Chintala, V.; Subramanian, K.A. Assessment of maximum available work of a hydrogen fueled compression ignition engine using exergy analysis. Energy 2014, 67, 162-175. [CrossRef]

24. Saidur, R.; BoroumandJazi, G.; Mekhilef, S.; Mohammed, H.A. A review on exergy analysis of biomass based fuels. Renew. Sustain. Energy Rev. 2012, 16, 1217-1222. [CrossRef]

25. Abedin, M.J.; Masjuki, H.H.; Kalam, M.A.; Sanjid, A.; Rahman, S.A.; Masum, B.M. Energy balance of internal combustion engines using alternative fuels. Renew. Sustain. Energy Rev. 2013, 26, 20-33. [CrossRef]

26. Chintala, V.; Kumar, S.; Pandey, J.K. A technical review on waste heat recovery from compression ignition engines using organic Rankine cycle. Renew. Sustain. Energy Rev. 2018, 81, 493-509. [CrossRef] 
27. Pandiyarajan, V.; Pandian, M.C.; Malan, E.; Velraj, R.; Seeniraj, R.V. Experimental investigation on heat recovery from diesel engine exhaust using finned shell and tube heat exchanger and thermal storage system. Appl. Energy 2011, 88, 77-87. [CrossRef]

28. Galindo, J.; Ruiz, S.; Dolz, V.; Royo-Pascual, L.; Haller, R.; Nicolas, B.; Glavatskaya, Y. Experimental and thermodynamic analysis of a bottoming Organic Rankine Cycle (ORC) of gasoline engine using swash-plate expander. Energy Convers. Manag. 2015, 103, 519-532. [CrossRef]

29. Kim, D.K.; Lee, J.S.; Kim, J.; Kim, M.S.; Kim, M.S. Parametric study and performance evaluation of an organic Rankine cycle (ORC) system using low-grade heat at temperatures below $80{ }^{\circ} \mathrm{C}$. Appl. Energy 2017, 189, 55-65. [CrossRef]

30. Fiaschi, D.; Manfrida, G.; Rogai, E.; Talluri, L. Exergoeconomic analysis and comparison between ORC and Kalina cycles to exploit low and medium-high temperature heat from two different geothermal sites. Energy Convers. Manag. 2017, 154, 503-516. [CrossRef]

31. Preißinger, M.; Schatz, S.; Vogl, A.; König-Haagen, A.; Brüggemann, D. Thermoeconomic analysis of configuration methods for modular Organic Rankine Cycle units in low-temperature applications. Energy Convers. Manag. 2016, 127, 25-34. [CrossRef]

32. Chen, H.; Goswami, D.Y.; Rahman, M.M.; Stefanakos, E.K. A supercritical Rankine cycle using zeotropic mixture working fluids for the conversion of low-grade heat into power. Energy 2016, 36, 549-555. [CrossRef]

33. Manfrida, G.; Secchi, R.; Stańczyk, K. Modelling and simulation of phase change material latent heat storages applied to a solar-powered Organic Rankine Cycle. Appl. Energy 2016, 179, 378-388. [CrossRef]

34. Hettiarachchi, H.M.; Golubovic, M.; Worek, W.M.; Ikegami, Y. Optimum design criteria for an organic Rankine cycle using low-temperature geothermal heat sources. Energy 2007, 32, 1698-1706. [CrossRef]

35. Yagli, H.; Koc, A.; Karakus, C.; Koc, Y. Comparison of toluene and cyclohexane as a working fluid of an organic Rankine cycle used for reheat furnace waste heat recovery. Int. J. Exergy 2016, 19, 420-438. [CrossRef]

36. Lai, N.A.; Wendland, M.; Fischer, J. Working fluids for high-temperature organic Rankine cycles. Energy 2011, 36, 199-211. [CrossRef]

37. Algieri, A.; Morrone, P. Comparative energetic analysis of high-temperature subcritical and transcritical Organic Rankine Cycle (ORC). A biomass application in the Sibari district. Appl. Therm. Eng. 2012, 36, 236-244. [CrossRef]

38. Vaja, I.; Gambarotta, A. Internal combustion engine (ICE) bottoming with organic Rankine cycles (ORCs). Energy 2010, 35, 1084-1093. [CrossRef]

39. Wang, T.; Zhang, Y.; Peng, Z.; Shu, G. A review of researches on thermal exhaust heat recovery with Rankine cycle. Renew. Sustain. Energy Rev. 2011, 15, 2862-2871. [CrossRef]

40. Wang, E.H.; Zhang, H.G.; Fan, B.Y.; Ouyang, M.G.; Zhao, Y.; Mu, Q.H. Study of working fluid selection of organic Rankine cycle (ORC) for engine waste heat recovery. Energy 2011, 36, 3406-3418. [CrossRef]

41. Benato, A.; Macor, A. Biogas engine waste heat recovery using organic Rankine cycle. Energies 2017, 10, 327. [CrossRef]

42. Glover, S.; Douglas, R.; De Rosa, M.; Zhang, X.; Glover, L. Simulation of a multiple heat source supercritical ORC (Organic Rankine Cycle) for vehicle waste heat recovery. Energy 2015, 93, 1568-1580. [CrossRef]

43. Dong, B.; Xu, G.; Luo, X.; Zhuang, L.; Quan, Y. Analysis of the supercritical organic Rankine cycle and the radial turbine design for high temperature applications. Appl. Therm. Eng. 2017, 123, 1523-1530. [CrossRef]

44. Xu, W.; Zhang, J.; Zhao, L.; Deng, S.; Zhang, Y. Novel experimental research on the compression process in organic Rankine cycle (ORC). Energy Convers. Manag. 2017, 137, 1-11. [CrossRef]

45. Fiaschi, D.; Innocenti, G.; Manfrida, G.; Maraschiello, F. Design of micro radial turboexpanders for ORC power cycles: From 0D to 3D. Appl. Therm. Eng. 2016, 99, 402-410. [CrossRef]

46. Braimakis, K.; Karellas, S. Energetic optimization of regenerative Organic Rankine Cycle (ORC) configurations. Energy Convers. Manag. 2018, 159, 353-370. [CrossRef]

47. Yu, H.; Eason, J.; Biegler, L.T.; Feng, X. Simultaneous heat integration and techno-economic optimization of Organic Rankine Cycle (ORC) for multiple waste heat stream recovery. Energy 2017, 119, 322-333. [CrossRef]

48. Yang, F.; Zhang, H.; Yu, Z.; Wang, E.; Meng, F.; Liu, H.; Wang, J. Parametric optimization and heat transfer analysis of a dual loop ORC (organic Rankine cycle) system for CNG engine waste heat recovery. Energy 2017, 118, 753-775. [CrossRef] 
49. Habibi, H.; Chitsaz, A.; Javaherdeh, K.; Zoghi, M.; Ayazpour, M. Thermo-economic analysis and optimization of a solar-driven ammonia-water regenerative Rankine cycle and LNG cold energy. Energy 2018, 149, 147-160. [CrossRef]

50. Feng, Y.; Zhang, Y.; Li, B.; Yang, J.; Shi, Y. Comparison between regenerative organic Rankine cycle (RORC) and basic organic Rankine cycle (BORC) based on thermoeconomic multi-objective optimization considering exergy efficiency and levelized energy cost (LEC). Energy Convers. Manag. 2015, 96, 58-71. [CrossRef]

51. Bilgiç, H.H.; Yağli, H.; Koç, A.; Yapici, A. Deneysel bir organik rankine çevriminde yapay sinir ağları (YSA) yardımıyla güç tahmini. Selcuk Univ. J. Eng. Sci. Technol. 2016, 4. [CrossRef]

52. Yağlı, H.; Koç, Y.; Koç, A.; Görgülü, A.; Tandiroğlu, A. Parametric optimization and exergetic analysis comparison of subcritical and supercritical organic Rankine cycle (ORC) for biogas fuelled combined heat and power (CHP) engine exhaust gas waste heat. Energy 2016, 111, 923-932. [CrossRef]

53. Cengel, Y.A.; Boles, M.A. Thermodynamics: An Engineering Approach, 6th ed.; McGraw-Hill Inc.: New York, NY, USA, 2008.

54. Bejan, A.; Tsatsaronis, G.; Moran, M. Thermal Design and Optimization; John Wiley: New York, NY, USA, 1996.

55. Dincer, I.; Rosen, M.A. Exergy: Energy, Environment and Sustainable Development, 2nd ed.; Elsevier: Amsterdam, The Netherlands, 2013.

56. Kotas, T.J. The Exergy Method of Thermal Plant Analysis; Elsevier: Amsterdam, The Netherlands, 2013.

57. Abuşoğlu, A.; Özahi, E.; Kutlar, A.İ.; Demir, S. Exergy analyses of green hydrogen production methods from biogas-based electricity and sewage sludge. Int. J. Hydrog. Energy 2017, 42, 10986-10996. [CrossRef]

58. Yağlı, H.; Karakuş, C.; Koç, Y.; Çevik, M.; Uğurlu, İ.; Koç, A. Designing and exergetic analysis of a solar power tower system for Iskenderun region. Int. J. Exergy 2019, 28, 96-112. [CrossRef]

59. NIST. Reference Fluid Thermodynamic and Transport Properties (REFPROP); Version 9.0; NIST: Gaithersburg, MD, USA, 2009.

60. Zhai, H.; An, Q.; Shi, L.; Lemort, V.; Quoilin, S. Categorization and analysis of heat sources for organic Rankine cycle systems. Renew. Sustain. Energy Rev. 2016, 64, 790-805. [CrossRef]

61. Tchanche, B.F.; Lambrinos, G.; Frangoudakis, A.; Papadakis, G. Low-grade heat conversion into power using organic Rankine cycles-A review of various applications. Renew. Sustain. Energy Rev. 2011, 15, 3963-3979. [CrossRef]

62. Chatzopoulou, M.A.; Markides, C.N. Thermodynamic optimisation of a high-electrical efficiency integrated internal combustion engine-Organic Rankine cycle combined heat and power system. Appl. Energy 2018, 226, 1229-1251. [CrossRef]

63. Zhang, J.; Zhang, H.; Yang, K.; Yang, F.; Wang, Z.; Zhao, G.; Liu, H.; Wang, E.; Yao, B. Performance analysis of regenerative organic Rankine cycle (RORC) using the pure working fluid and the zeotropic mixture over the whole operating range of a diesel engine. Energy Convers. Manag. 2014, 84, 282-294. [CrossRef]

64. Xi, H.; Li, M.J.; Xu, C.; He, Y.L. Parametric optimization of regenerative organic Rankine cycle (ORC) for low grade waste heat recovery using genetic algorithm. Energy 2013, 58, 473-482. [CrossRef]

65. Fernández, F.J.; Prieto, M.M.; Suárez, I. Thermodynamic analysis of high-temperature regenerative organic Rankine cycles using siloxanes as working fluids. Energy 2011, 36, 5239-5249. [CrossRef]

66. Wang, E.; Yu, Z.; Zhang, H.; Yang, F. A regenerative supercritical-subcritical dual-loop organic Rankine cycle system for energy recovery from the waste heat of internal combustion engines. Appl. Energy 2017, 190, 574-590. [CrossRef]

67. Kemp, R.; Schot, J.; Hoogma, R. Regime shifts to sustainability through processes of niche formation: The approach of strategic niche management. Technol. Anal. Strateg. Manag. 1998, 10, 175-198. [CrossRef]

68. Oyewunmi, O.A.; Ferré-Serres, S.; Lecompte, S.; van den Broek, M.; De Paepe, M.; Markides, C.N. An assessment of subcritical and trans-critical organic Rankine cycles for waste-heat recovery. Energy Procedia 2017, 105, 1870-1876. [CrossRef]

69. Latz, G.; Andersson, S.; Munch, K. Comparison of Working Fluids in Both Subcritical and Supercritical Rankine Cycles for Waste-Heat Recovery Systems in Heavy-Duty Vehicles (No. 2012-01-1200); SAE Technical Paper; SAE International: Warrendale, PA, USA, 2012.

70. Chowdhury, J.; Nguyen, B.K.; Thornhill, D.; Hu, Y.; Soulatiantork, P.; Balta-Ozkan, N.; Varga, L. Fuzzy Nonlinear Dynamic Evaporator Model in Supercritical Organic Rankine Cycle Waste Heat Recovery Systems. Energies 2018, 11, 901. [CrossRef] 
71. Mago, P.J.; Chamra, L.M.; Srinivasan, K.; Somayaji, C. An examination of regenerative organic Rankine cycles using dry fluids. Appl. Therm. Eng. 2008, 28, 998-1007. [CrossRef]

72. Mosaffa, A.H.; Mokarram, N.H.; Farshi, L.G. Thermo-economic analysis of combined different ORCs geothermal power plants and LNG cold energy. Geothermics 2017, 65, 113-125. [CrossRef]

73. Reis, M.M.L.; Gallo, W.L. Study of waste heat recovery potential and optimization of the power production by an organic Rankine cycle in an FPSO unit. Energy Convers. Manag. 2018, 157, 409-422. [CrossRef]

74. Javanshir, A.; Sarunac, N.; Razzaghpanah, Z. Thermodynamic Analysis of ORC and Its Application for Waste Heat Recovery. Sustainability 2017, 9, 1974. [CrossRef]

75. Yasa, T. Thermodynamic evaluation of energy recovery system for heavy duty diesel engine by using organic rankine cycle. Anadolu Univ. Sci. Technol. A Appl. Sci. Eng. 2017, 18. [CrossRef]

76. Ayub, A.; Sheikh, N.A.; Tariq, R.; Khan, M.M.; Invernizzi, C.M. Exergetic optimization and comparison of combined gas turbine supercritical CO2 power cycles. J. Renew. Sustain. Energy 2018, 10, 044703. [CrossRef]

77. Abam, F.I.; Ekwe, E.B.; Effiom, S.O.; Ndukwu, M.C. A comparative performance analysis and thermo-sustainability indicators of modified low-heat organic Rankine cycles (ORCs): An exergy-based procedure. Energy Rep. 2018, 4, 110-118. [CrossRef]

78. Anvari, S.; Jafarmadar, S.; Khalilarya, S. Proposal of a combined heat and power plant hybridized with regeneration organic Rankine cycle: Energy-Exergy evaluation. Energy Convers. Manag. 2016, 122, 357-365. [CrossRef]

(C) 2019 by the authors. Licensee MDPI, Basel, Switzerland. This article is an open access article distributed under the terms and conditions of the Creative Commons Attribution (CC BY) license (http:/ / creativecommons.org/licenses/by/4.0/). 